УДК 902/904 https://doi.org/10.24852/2587-6112.2021.1.298.323

\title{
ПОГРЕБЕНИЯ ЛУГОВСКОЙ КУЛЬТУРЫ МУРЗИХИНСКОГО ІІ МОГИЛЬНИКА В ПРИУСТЬЕВОМ ЗАКАМЬЕ
}

\author{
(C) 2021 г. А.В. Лыганов, А.А. Чижевский
}

Мурзихинский II могильник - поликультурный некрополь, который использовался на протяжении нескольких тысяч лет с эпохи энеолита и до раннего железного века. В данной статье рассматриваются погребения позднего бронзового века, которые относятся к луговской культуре. Большая часть погребений совершалась скорченно, на левом боку и лишь одно захоронение было совершено по обряду кремации. В межмогильном пространстве отмечены жертвенные комплексы, состоящие из разбитых сосудов. Погребальный инвентарь представлен плоскодонной керамикой и металлическими предметами, причем все изделия из металла выявлены в погребениях, не содержащих керамику. Некоторые сосуды были орнаментированы в традициях поздняковской культуры. Наиболее яркой находкой является двулезвийный кинжал, который относится к лобойковско-дербеденовской группе металлических изделий позднего бронзового века. Другой необычной находкой из металла была литая бронзовая бусина. Данные стратиграфии, радиоуглеродного анализа и аналогии позволяют высказать предположение о наличии в могильнике двух хронологически разных групп погребений луговской культуры: ранних, организованных в группы, и поздних - одиночных. Для одиночных погребений имеется определение радиоуглеродного возраста 1538-1400 кал. л. до н.э.

Ключевые слова: археология, Куйбышевское водохранилище, р. Кама, могильник, погребение, жертвенный комплекс, поздний бронзовый век, луговская культура, поздняковская культура.

\section{BURIALS OF LUGOVSKAYA CULTURE FROM MURZIKHA II BURIAL GROUND IN THE ESTUARY TRANS-KAMA REGION}

\section{A. V. Lyganov, A. A. Chizhevsky}

The Murzikha II burial ground is a multicultural necropolis which operated for several thousand years from the Eneolithic to the Early Iron Age. This paper addresses the burials of the Late Bronze Age belonging to the Lugovskaya culture. Most of the burials were performed with the deceased in a crouched position on the left side, and only one burial was performed using a cremation rite. The space between graves contained sacrificial complexes consisting of broken vessels. The burial items are represented by flat-bottomed ceramics and metal objects, whereby all metal items were found in burials which did not contain ceramics. Some of the vessels were decorated in the tradition of the Pozdniakovo culture. The most notable find is a double-edged dagger belonging to Loboikovka-Derbeden group of metal items of the Late Bronze Age. Another unusual metal find was a cast bronze bead. The stratigraphy and radiocarbon analysis data and analogies make it possible to suggest that two chronologically different groups of burials of the Lugovskaya culture exist in the burial ground: early, organized in groups, and late - single burials. For single burials, the following radiocarbon age was determined - 1538-1400 BC.

Keywords: archaeology, Kuybyshev reservoir, Kama River, burial ground, burial, sacrificial complex, Late Bronze Age, Lugovskaya culture, Pozdnyakovo culture.

Мурзихинский II могильник располагается в полузатопленной камской пойме в Алексеевском районе Республики Татарстан, в 4,9 км к северу-северо-западу от западной окраины с. Алексеевское и в 5,6 км к юго-востоку от c. Сорочьи Горы Рыбно-Слободского района РТ. До затопления Куйбышевским водохранилищем территория, занимаемая некрополем, являлась низкой речной террасой, располагавшейся вдоль левого берега р. Архаровки - левого притока р. Кама. После заполнения ложа водохранилища здесь образовался остров, который у местного населения получил название «Милицейский». В северной части этого острова и был выявлен могильник. В настоящее время по острову проходит

дамба мостового перехода через реку Кама, а большая часть территории могильника занята пескохранилищем (рис. 1, 2).

Могильник был открыт Е.А. Беговатовым в 1983 году. Тогда, при низком уровне воды в водохранилище, в размыве берега были обнаружены разрушенные погребения и отдельные вещи, относящиеся к финалу бронзового и раннему железному векам (Беговатов, Марков, 1992). В 1984 г на месте наибольшей концентрации находок был заложен небольшой раскоп, в котором погребений выявлено не было. Однако, в размыве берега в стороне от раскопа, было выявлено парное погребение финала эпохи бронзы и собран богатый подъемный материал ананьинской КИО и макла- 
шеевской культуры (Беговатов, Марков, 1992, c. 57-70). В дальнейшем, на многие годы исследования были приостановлены из-за высокого уровня воды в Куйбышевском водохранилище.

В 1995-2000 гг. Новостроечная экспедиция Главного управления охраны и использования памятников истории и культуры РТ под руководством А.А. Чижевского, совместно с экспедицией НЦАИ АН РТ производила охранно-спасательные работы на Мурзихинском II могильнике, попавшем в зону строительства мостового перехода через р. Кама. Исследования на памятнике осуществлялись на протяжении шести лет. В результате этих работ 16 раскопами были вскрыты 233 погребения, которые относились преимущественно к финалу позднего бронзового века - маклашеевской культуре, и к раннему железному веку - ананьинской КИО (Чижевский, 2008). Кроме того, на территории могильника выявлены энеолитические погребения (Чижевский, 2008; Чижевский, Шипилов, 2018) и группа погребений бронзового века - луговской культуры, часть из которых была опубликована ранее (Марков, Чижевский, 2003; Чижевский, 2004).

В данной статье мы рассмотрим именно последнюю группу погребений. Всего за 1995-2000 гг. было изучено 17 погребений луговской культуры, которые содержали останки 18 людей. Они расположены на одной линии, состоящей из раскопов I, IV, V, VIII$\mathrm{XI}, \mathrm{XV}$. В соседней линии раскопов, каких либо находок луговского времени не найдено. Погребения в раскопах располагались поодиночке и группами. Возле этих захоронений фиксировались развалы сосудов и отдельные фрагменты керамики, по-видимому, относящиеся к жертвенным комплексам. Каких либо возвышений над групповыми или одиночными погребениями не отмечено. Не зафиксированы следы насыпей и в стратиграфических разрезах раскопов. Однако, судя по концентрации погребений и жертвенных комплексов на определенных участках, можно предполагать наличие здесь в древности невысоких курганных насыпей, полностью уничтоженных на сегодняшний день.

Если принять за основу вышеизложенное, то планиграфия Мурзихинского II могильника эпохи позднего бронзового века могла быть организована следующим образом: курганы, имевшие разные размеры в зависимости от количества погребений, были вытянуты цепочкой длиной в 140 м почти строго по направлению север - юг с небольшим отклонением к северу-северо-востоку и югу-югозападу.

Стратиграфия Мурзихинского II могильника на всех раскопах стандартная и выглядит следующим образом: дерн - около 10 см; рыхлый серый суглинок - 15-20 см; плотный темно-серый суглинок - 40-50 см; материк - желтая глина - ниже. Следует отметить, что очертания могильных ям выявить не удалось, поскольку костяки были зафиксированы на глубине 40-80 см от поверхности, в слое темно-серого суглинка. Были выявлены только очертания погребения-кремации 18 по пятну рыже-красного цвета (табл.1).

\section{Раскоп I, 1995 год}

Выявлено пять компактно расположенных погребений луговской культуры $(11,13,15$, $18,20)$, над которыми в древности, возможно, существовала небольшая курганная насыпь. Погребения 11, 13, 18, 20 были вытянуты в линию с юго-запада на северо-восток, погребение 15 расположено в стороне - к юговостоку от погребения 13. В центральной части этой группы погребений находилось несколько развалов сосудов и скоплений керамики луговской культуры (рис. 3).

Погребение 11 (рис. 3; 4: 1, 2). Контуры могильной ямы не выявлены. На глубине 60 см от современной поверхности были отмечены кости человека. Костяк хорошей сохранности залегал скорченно на левом боку, головой он был ориентирован на юго-восток. Руки погребенного были согнуты и прижаты к груди, колени подтянуты вплотную к рукам. Погребение принадлежало женщине 25-30 лет. В изголовье за затылком был помещен лепной плоскодонный глиняный сосуд с примесью мелкого шамота и органики в глиняном тесте. Он орнаментирован оттисками гребенчатого штампа в виде двух зигзагообразных горизонтальных линий, параллельных друг другу, окаймленных в верхней и нижней частях парными линиями, нанесенными тем же штампом.

Погребение 13 (рис. 3; 4: 3, 4). Очертания могильной ямы не обнаружены. На глубине 70 см от современной поверхности выявлено разрушенное погребение женщины. Сохранился лишь лежащий на левом боку череп, верхом головы ориентированный на восток, а также кости предплечья и фрагменты костей голени. У затылочной части черепа был зафиксирован лепной плоскодонный сосуд с примесью мелкого шамота и органики в глиняном тесте, со слабо намеченной 
низкой горловиной. Сосуд в своей верхней трети украшен орнаментом в виде тройного наклонного штампа, ограниченного в верхней и нижней частях тремя рядами узких горизонтальных линий. Ниже располагается орнаментальная зона в виде горизонтальных ромбов, образованных двойными прочерченными и перекрещивающимися линиями. Пространство внутри ромбов и над ними заполнено оттисками двузубого приостренного штампа.

Погребение 15 (рис. 3; 4: 5, 6). Детское погребение было выявлено на глубине 70 см от современной поверхности. Очертания могильной ямы не прослеживаются, сохранность костей плохая. Судя по расположению костей, ребенок был похоронен скорчено на правом боку, головой на север. У лицевой части черепа был зафиксирован лепной плоскодонный сосуд с примесью мелкого шамота и органики в глиняном тесте. Он имел горшковидную форму с невысокой отогнутой наружу шейкой и выраженным плечиком. Сосуд орнаментирован по шейке тремя горизонтальными линиями, нанесенными гребенчатым штампом. Плечики сосуда украшены флажковым орнаментом, выполненным гладким штампом.

Погребение 18 (рис. 3; 5: 1-3). Было зафиксировано на глубине 25 см от современной поверхности в слое темно-серой супеси. Очертания могильной ямы подтрапецевидной в плане формы выявлены по полосе обожженной земли рыже-красного цвета. Внутри этого большого пятна на глубине 30 см выделяется пятно меньших размеров, насыщенное обожженным рыхлым грунтом овальной в плане формы. Размеры могильной ямы $120 \times 95$ см, размеры пятна внутри нее $43 \times 30$ см. Захоронение ориентировано по линии запад-северо-запад - восток-юговосток. Заполнение могильной ямы отличается интенсивным черным цветом по сравнению с окружающим грунтом.

Описание данного погребения, ввиду неполного состояния костяка и наличия костных остатков и погребального инвентаря вне контуров могильной ямы, представляет определенную трудность. Поэтому описание делится на три части.

1. Костные остатки и инвентарь вне пределов могильной ямы. Рядом с пятном могильной ямы и за его приделами у южного угла погребения расчищены фрагменты таза и сильно разрушенные косточки. Тазовые кости принадлежат человеку. В 10 см к западу от тазовых костей отмечены остатки головки бедренной кости. В районе западного угла погребения за пределами прослойки прокаленной глины располагалась длинная трубчатая кость человека. Рядом с ней отмечен фрагмент венчика глиняного сосуда орнаментированного по верхней части шейки оттисками потреугольного штампа и двумя рядами горизонтального зигзага. У северо-западной стенки погребения зафиксированы кроме того позвонки человека и в 20 см от длинной кости отмечен человеческий зуб. Все фрагменты костей и керамики вне пятна могильной ямы залегали на глубине 25-30 см от уровня современной поверхности.

2. Внутри могильной ямы на глубине 30-60 см от современной поверхности в восточной части погребения отмечены фрагменты керамики и кости человека. В западной части погребения выявлены фрагменты нижней челюсти человека и отдельные кости.

3. При расчистке малого пятна прокала на глубине 30-50 см от современной поверхности были выявлены бронзовая бочонковидная бусина, и кости: зуб, позвонки, бедренная кость и другие фрагменты человеческого костяка. Необходимо отметить, что глубина залегания полосы обожженной земли, окаймляющей большое пятно, составляет 5-7 см от уровня фиксации очертаний могильной ямы, а малого пятна 10-12 см.

Разрозненные кости человека определены как принадлежавшие женщине.

Погребение 20 (рис. 3; 5: 4, 5). Очертания могильной ямы не зафиксированы. На глубине 80 см от современной поверхности в слое темно-серой супеси расчищен костяк мужчины 25-30 лет. Умерший лежал скорченно на правом боку головой на юго-восток. Сохранность костей хорошая. У лица отмечен лепной плоскодонный сосуд с примесью мелкого шамота и органики в глиняном тесте. Он имел низкую горловину и выраженное плечико. Орнамента на сосуде нет.

Кроме погребений, в раскопе I, 1995 года отмечены скопления керамики и четыре развала сосудов, всего 256 фрагментов (рис. 6). Большая часть (189 фрагментов) выявлена на уч. 32, расположенном между погребениями 13, 15 и 18, остальные рассеяны вокруг погребений эпохи бронзы, и, в единичных экземплярах, по всей площади раскопа. Удалось реконструировать верхнюю часть четырех крупных развалов происходящих с уч. 32. Первый, развал сосуда баночной формы, украшен рядами хаотично поставленных крупных 
овальных и каплевидных вдавлений (рис. 6: $10,11)$. Второй, развал горшковидного сосуда с выраженной шейкой, украшен под венчиком рядом из заштрихованных треугольников вершинами вниз, далее на переходе от шейки в плечико располагаются два ряда горизонтальных линий нанесенных протаскиванием гребенки, еще ниже располагаются крупные заштрихованные треугольники вершинами вниз, с бахромой из вдавлений (рис. 6: 12). Третий крупный развал представлен фрагментами керамики с орнаментом из горизонтальных линий и заштрихованных треугольников вершинами вниз с бахромой из овальных вдавлений (рис. 6: 9). Четвертый развал состоит из мелких не восстанавливаемых фрагментов керамики с «елочным» орнаментом (рис. 6: 1-4).

\section{Раскоп IV, 1996 год}

Выявлена вторая группа погребений, расположенных компактно на одной территории, это погребения 83-85.

Погребение 83 (рис. 3; 7: 1, 2). Очертания могильной ямы не прослеживаются. На глубине 30 см от современной поверхности выявлены кости ребенка плохой сохранности. Судя по сохранившимся костным останкам, погребенный был ориентирован головой на северо-восток. Кости рук, позвоночника и ребра не сохранились. В 15 см к юго-западу от черепа выявлены перемешанные косточки ног и два ребра ребенка. Непосредственно к восточной стороне черепа примыкал плоскодонный лепной сосуд без орнамента с примесью шамота в глиняном тесте. В 10 см к юго-западу от черепа зафиксирована плохо сохранившаяся кость животного. В 55 см к югу от костей ног ребенка отмечен фрагмент неорнаментированного лепного сосуда, который, однако, возможно, не связан с этим погребением.

Погребение 84 (рис. 3; 7: 3-5). Очертания могильной ямы не выявлены. Парное погребение 84 эпохи бронзы оказалось перекрыто, также двойным погребением 81 ананьинской КИО раннего железного века. На глубине 60 см от современной поверхности выявлены человеческие кости, принадлежавшие двум костякам. Сохранность костей хорошая. Костяки пронумерованы слева направо

Костяк I женский, 16-18 лет, был ориентирован головой на восток, лицом обращен на юго-восток. Нижняя челюсть опущена. Умершая лежала на левом боку, с сильно согнутыми в коленях ногами, правая бедренная кость изъята вовремя выемки грунта для погребе- ния 81 раннего железного века и помещена над черепом костяка I. Руки согнуты в локтях и лежат ладонями на горле.

Костяк II мужской, 25-35 лет, располагался на левом боку юго-западнее костяка І. Он был ориентирован головой на юго-восток, лицом на юго-запад. Руки покойного были согнуты и вывернуты таким образом, что локти смотрели вперед. Кисти рук лежали в районе таза. Ноги были сильно согнуты в коленях. Под левым предплечьем найден бронзовый кинжал, острием ориентированный на северо-запад. У правого колена погребенного расчищен фрагмент венчика лепного сосуда с рядом овальных вдавлений по шейке. Подобные фрагменты керамики залегают и в межмогильном пространстве между погребениями 83, 84, 85 (рис. 7: 8, 9).

Погребение 85 (рис. 3; 7: 6, 7). Очертаний могильной ямы не зафиксировано. Костяк человека хорошей сохранности лежал на глубине 60 см от современной поверхности на левом боку. Он был ориентирован головой на восток-юго-восток, лицом обращен к югу. Нижняя челюсть опущена. Погребенный лежал на левом боку с ногами, сильно согнутыми в коленях. Правая рука согнута в локте и предплечьем лежит в районе живота. Левая рука вытянута вдоль тела таким образом, что кость предплечья размещается под костью бедра. Рядом с лицом лежала бронзовая четырехгранная проколка, ориентированная по оси северо-восток юго-запад. Погребение предположительно мужское, возраст около 18 лет.

\section{Раскоп V, 1997 год}

В раскопе $\mathrm{V}$ выявлено одно разрушенное погребение эпохи бронзы, вокруг которого отмечены фрагменты и скопления керамики.

Погребение 98 (рис. 3; 8: 1). Следы могильной ямы не зафиксированы. Разрушенный костяк человека лежал скорченно на правом боку и, вероятнее всего, был ориентирован головой на восток. Он выявлен на глубине 72 см от современной поверхности. Вся верхняя часть костяка отсутствует, начиная от среднего отдела позвоночника. Ноги сильно поджаты (голени плотно подходят к костям бедра), но не поднимаются выше тазовых костей. Рядом с позвоночным столбом найдена лучевая кость. На самом позвоночнике найден скол кремня. Череп и плечевая кость обнаружены в стороне, в ногах костяка погребения 97 ананьинской КИО раннего железного века, куда они были перемещены после разрушения погребения 98. 
В округе погребения выявлены два скопления лепной неорнаментированной керамики, от сосудов баночной формы, с примесью шамота в глиняном тесте (рис. 8: 2).

\section{Раскоп IX, 1998 год}

Раскоп IX - самый южный, здесь было выявлено два погребения под номерами 150 и 144, которые, возможно, были совершены под одной насыпью. Погребение 152 и жертвенный комплекс из раскопа $\mathrm{X}$ относятся к другой группе. Возможно, за пределами этих раскопов остались неисследованные погребения.

Погребение 144 (рис. 3 9: 1-4). Очертания могильной ямы не зафиксированы. Костяк человека был выявлен на глубине 45 см. Он ориентирован головой на юго-восток. Погребенный лежал на левом боку, с согнутыми в коленях ногами. Лицом он обращен на югозапад. Левая рука вытянута вдоль тела, правая согнута в локте. За черепом выявлена медная пронизь. Рядом с правой лопаткой отмечена медная круглая бляха с отверстиями для нашивания в центре. Рядом с костями левого предплечья найден бронзовый двулезвийный нож с отломанным кончиком, рукоятью он обращен на юго-восток.

Погребение 150 (рис. 3; 9: 5, 6). Могильная яма не выявлена. Костяк ребенка обнаружен на глубине $50 \mathrm{~cm}$. Он ориентирован головой на северо-восток. Погребенный лежал на левом боку, руки были согнуты в локтях и лежали перед грудью, ноги согнуты в коленях. За черепом был зафиксирован глиняный плоскодонный горшок, с примесью раковины в глиняном тесте, орнаментированный оттисками зубчатого штампа и ямками в виде кольцевых углублений. Последние располагались тремя поясками, два шли по горловине и плечику, один - по придонной части. Гребенчатый штамп в виде строенного зигзага шел по средней части тулова, а орнамент в виде гребенчатого штампа располагался зонами, перпендикулярными друг другу по три оттиска в ряд и накладывался на пояски с ямками в верхней части.

Между погребениями отмечены несколько одиночных фрагментов керамики эпохи бронзы.

Погребение 152 (рис. 3; 7). Очертания могильной ямы не выявлены. На глубине 25 см обнаружен костяк ребенка, расположенный на левом боку. Ноги были согнуты в коленях. Сопровождающий инвентарь не зафиксирован.
В межмогильном пространстве выявлено множество мелких фрагментов керамики эпохи бронзы. В примыкающем к раскопу IX раскопе X эти находки продолжались.

\section{Раскоп X, XI, 1999 год}

В раскопе X выявлены многочисленные фрагменты керамики и развал целого сосуда (рис. 10: 1-4, 7). В раскопе XI обнаружены два одиночных погребения, находившиеся в северной части, и два развала сосудов из жертвенных комплексов, связанных в южной части с группой погребений 222, 224, 225 (рис. 10: $10,11)$. Здесь же зафиксирован единственный на всей раскопанной площади могильника фрагмент сосуда с валиком (рис. 10: 1).

Погребение 155 (рис. 3; 10: 5, 6). Могильная яма не выявлена. Костяк мужчины 35-45 лет плохой сохранности лежал на левом боку. Головой он был ориентирован на северо-запад. Левая рука вытянута вдоль тела, правая согнута в локте. Позвоночник и ребра не сохранились. Ноги согнуты в коленях под углом $45^{\circ}$, бедренные кости расположены перпендикулярно по отношению к костяку. У правого локтя отмечено два фрагмента керамики, у левого - галька. В одном метре к югозападу от ног погребенного отмечен фрагмент керамики. Под костяком погребенного зафиксирован небольшой бронзовый нож.

Погребение 160 (рис. 10: 8, 9). Могильная яма не выявлена. Костяк женщины 18-20 лет обнаружен на глубине 40 см. Он ориентирован головой на юго-восток. Погребенная лежала на левом боку, руки согнуты в локтях и лежали перед грудью, ноги согнуты в коленях. Бедренные кости находятся под углом $45^{\circ}$ по отношению к позвоночнику. За черепом зафиксирован глиняный плоскодонный горшок с примесью раковины в глине. Сосуд орнаментирован под венчиком тремя рядами горизонтальных каннелюр, ниже вершинами вниз располагались заштрихованные треугольники.

Помимо этого в южной части раскопа в парном погребении 175 ананьинской КИО раннего железного века от пояса костяка I и до берцовых костей костяка II, в засыпи лежали в ряд фрагменты неорнаментированного плоскодонного сосуда баночной формы эпохи бронзы (рис. 10: 11). Данное погребение расположено в непосредственной близи от группы погребений 222, 224, 225 эпохи бронзы. Поблизости от погребения 175 зафиксирован жертвенный комплекс, состоявший из развала сосуда раннего железного века и стенки сосуда эпохи бронзы. 


\section{Раскоп XV, 2000 год}

Выявлена группа из трех погребений и придонная часть сосуда из межмогильного пространства. К этой же группе относятся находки развалов сосудов в погребении 175 и жертвенного комплекса выявленные на раскопе XI.

Погребение 222 (рис. 3; 11: 1-3). Могильная яма не выявлена. Костяк взрослого человека, зафиксирован на глубине 30 см, он лежал скорченно на правом боку и был ориентирован головой на восток северо-восток. Череп обращен лицом на северо-запад, нижняя челюсть упала и лежит зубами вниз. Кости правой руки не сохранились, левая рука лежала перед грудью в согнутом положении. Ноги согнуты в коленях и располагаются друг относительно друга под углом $90^{\circ}$. В засыпи погребения отмечен зуб травоядного животного. Рядом с затылочной частью черепа найден развал лепного плоскодонного сосуда. Сосуд орнаментирован под венчиком двумя рядами горизонтальных линий, образованных протаскиванием гребенки, под которыми расположено поле из вписанных друг в друга заштрихованных линиями треугольников, расположенных вершинами вверх и вниз. Затем следует поле из отпечатков гребенчатого штампа в виде ряда горизонтальной «елочки», сверху и снизу оконтуренное горизонтальными линиями из протащенной гребенки. В 20 см от лица костяка выявлен фрагмент лепного сосуда. У колен обнаружен второй плоскодонный сосуд с орнаментом в виде ряда полуовальных вдавлений.

Погребение 224 (рис. 3; 11: 4, 5). Могильная яма не выявлена. Костяк взрослого человека зафиксирован на глубине 40 см. Он лежал скорченно на левом боку и был ориентирован головой на восток. Череп обращен лицом на юго-запад. Руки лежали перед грудью в согнутом положении, кисти рук отмечены перед лицом. Ноги сильно согнуты в коленях и располагаются друг относительно друга под углом $45^{\circ}$. Под черепом и плечами отмечена глиняная подсыпка дна погребения в виде полумесяца размерами $90 \times 40$ см и толщиной 1-2 см. Рядом с верхней частью черепа найден лепной плоскодонный сосуд с орнаментом в виде двух ряда полуовальных и подтреугольных вдавлений.

Погребение 225 (рис. 3; 11: 6, 7). Могильная яма не выявлена. Костяк ребенка зафиксирован на глубине $50 \mathrm{~cm}$. Он лежал скорченно на левом боку и был ориентирован головой на юго-восток. Череп обращен лицом на запад.
Правая рука лежала перед грудью в согнутом положении, кости кисти лежали перед лицом. Левая рука не сохранилась. Ноги сильно согнуты в коленях и располагаются относительно друг друга под углом $45^{\circ}$. Рядом с затылочной костью черепа найден небольшой неорнаментированный плоскодонный сосуд баночной формы.

Хронология и культурная принадлежность погребений эпохи бронзы Мурзихинского II могильника базируется на стратиграфических наблюдениях, аналогиях в погребальном обряде, керамике и металле в культурах позднего бронзового века Северной Евразии и данных радиоуглеродного анализа.

1. Стратиграфические наблюдения. Погребения 13, 84, 98 перекрыты и частично разрушены погребениями АКИО. В парном ананьинском погребении 175, как было отмечено выше, зафиксированы фрагменты плоскодонного горшка, выложенные в ряд от одного костяка к другому. Вероятно, этот сосуд относится к жертвенному комплексу группы погребений 222, 224, 225. Таким образом, судя по стратиграфии, изучаемые погребения были совершены до погребений раннего железного века, и их следует датировать более ранним временем.

2. Погребальный обряд и его аналогии (табл. 1).

Погребальные сооружения и останки погребенных. Как уже отмечалось выше, могильные ямы на Мурзихинском II могильнике не были выявлены из-за того, что они располагались на небольшой глубине в слое темно-серого суглинка. По рыже-красному цвету обожженной земли на глубине 25 см удалось зафиксировать форму и размеры ямы погребения 18. Она имела неправильную подтрапециевидную форму размерами $120 \times 95$ см. Подобный обряд погребения зафиксирован в Коминтерновских курганах. Здесь было выявлено три погребения (погр. 1, 5 кургана 2 и погр. 1 кургана 1), ямы которых фиксировались по ярко-красному прокалу. Была отмечена и неправильная - подчетырехугольная форма могильных ям на уровне фиксации (Чижевский и др., 2011, с. 267-269; Лыганов, 2017, рис. 4, 5). Разнообразные огненные ритуалы зафиксированы и в могильниках Такталачук и Балымский (Казаков, 1978, с. 82; Калинин, Халиков, 1954, c. 202). Кремация погребенных и различные огненные ритуалы известны для черкаскульской культуры Зауралья, поздняковской культуры Верхнего Поволжья и Поочья (Обыден- 
Таблица 1. Погребальный обряд луговских погребений Мурзихинского II могильника

Table 1. Burial rite of the Lugovskaya culture burials of the Murzikha II burial ground

\begin{tabular}{|c|c|c|c|c|c|c|c|c|}
\hline $\begin{array}{l}\text { № } \\
\text { на- } \\
\text { сы- } \\
\text { пи? }\end{array}$ & $\begin{array}{c}\text { № } \\
\text { погр }\end{array}$ & $\begin{array}{c}\text { Поза, } \\
\text { бок }\end{array}$ & $\begin{array}{c}\text { Глубина } \\
\text { залегания } \\
\text { костяка }\end{array}$ & $\begin{array}{c}\text { Перекрытые } \\
\text { погребениями } \\
\text { РЖВ }\end{array}$ & Ориентировка & $\begin{array}{c}\text { расположение } \\
\text { сосуда }\end{array}$ & $\begin{array}{c}\text { металл } \\
\text { инвентарь }\end{array}$ & $\begin{array}{c}\text { пол/ } \\
\text { возраст }\end{array}$ \\
\hline \multirow[t]{5}{*}{1} & 11 & лев. & $-60 \mathrm{~cm}$ & & юго-восток & за черепом & - & $\begin{array}{l}\text { жен/25- } \\
30 \text { лет }\end{array}$ \\
\hline & 13 & лев. & $-70 \mathrm{~cm}$ & угол погр.№12 & восток & за черепом & - & жен/? \\
\hline & 15 & прав. & $-70 \mathrm{~cm}$ & - & север & перед лицом & - & детск \\
\hline & 18 & $\begin{array}{l}\text { крема- } \\
\text { ция }\end{array}$ & $-25-60 \mathrm{~cm}$ & - & - & - & бронзовая бусина & $\begin{array}{c}\text { жен ? до } \\
21 \text { года }\end{array}$ \\
\hline & 20 & прав. & $-80 \mathrm{~cm}$ & - & юго-восток & перед лицом & - & $\begin{array}{c}\text { муж/25- } \\
\text { 30лет }\end{array}$ \\
\hline \multirow[t]{4}{*}{2} & 83 & - & $-30 \mathrm{~cm}$ & - & северо-восток & возле черепа? & - & детск \\
\hline & $\begin{array}{c}84 \\
\text { костяк } \\
1\end{array}$ & лев. & $-60 \mathrm{~cm}$ & $\begin{array}{c}\text { перекрыт погр. } \\
\text { №81 }\end{array}$ & восток & - & - & $\begin{array}{c}\text { жен/ 16- } \\
18 \text { лет }\end{array}$ \\
\hline & $\begin{array}{c}84 \\
\text { костяк } \\
2\end{array}$ & лев. & $-60 \mathrm{~cm}$ & $\begin{array}{c}\text { перекрыт погр. } \\
\text { №81 }\end{array}$ & юго-восток & - & $\begin{array}{c}\text { кинжал в } \\
\text { районе левого } \\
\text { предплечья }\end{array}$ & $\begin{array}{c}\text { муж/25- } \\
\text { 35лет }\end{array}$ \\
\hline & 85 & лев. & $-60 \mathrm{~cm}$ & - & $\begin{array}{c}\text { восток юго- } \\
\text { восток }\end{array}$ & - & $\begin{array}{c}\text { проколка перед } \\
\text { лицом }\end{array}$ & $\begin{array}{c}\text { муж/18 } \\
\text { лет }\end{array}$ \\
\hline 3 & 98 & прав. & $-72 \mathrm{~cm}$ & $\begin{array}{l}\text { разрушен } \\
\text { погр.№97 }\end{array}$ & восток & - & - & - \\
\hline \multirow[t]{2}{*}{4} & 144 & лев. & -45 & - & юго-восток & - & $\begin{array}{c}\text { нож рядом с } \\
\text { костями левого } \\
\text { предплечья; } \\
\text { за черепом } \\
\text { медная пронизь, } \\
\text { рядом с правой } \\
\text { лопаткой бляха с } \\
\text { отверстиями } \\
\end{array}$ & - \\
\hline & 150 & лев. & $-50 \mathrm{~cm}$ & - & северо-восток & за черепом & - & детск \\
\hline 5 & 152 & лев. & $-25 \mathrm{~cm}$ & - & юг? & - & - & детск \\
\hline 6 & 155 & лев. & $-38 \mathrm{~cm}$ & - & северо-запад & & Нож под костяком & $\begin{array}{c}\text { муж/35- } \\
46 \text { лет }\end{array}$ \\
\hline 7 & 160 & лев. & $-40 \mathrm{~cm}$ & - & юго-восток & перед лицом & - & $\begin{array}{c}\text { жен/18- } \\
20 \text { лет }\end{array}$ \\
\hline \multirow[t]{3}{*}{8} & 222 & прав. & $-30 \mathrm{~cm}$ & - & $\begin{array}{c}\text { восток северо- } \\
\text { восток }\end{array}$ & $\begin{array}{c}\text { 1. за черепом, } 2 . \\
\text { под коленями }\end{array}$ & - & - \\
\hline & 224 & лев. & $-40 \mathrm{~cm}$ & - & восток & $\begin{array}{c}\text { верхняя часть } \\
\text { черепа }\end{array}$ & - & - \\
\hline & 225 & лев. & $-50 \mathrm{~cm}$ & - & юго-восток & за черепом & - & детск? \\
\hline
\end{tabular}

* Половозрастные определения произведены А.А. Хохловым

нов, Шорин, 2005, с. 60; Бадер, Попова, 1987, c. 132).

Следует отметить, что большая часть могильных ям погребений луговской и черкаскульской культур Прикамья, исследованных в курганных группах Коминтерновских и Маклашеевских на взвозе и в могильниках Деуковском I и Такталачук, также не фиксируется из-за малой глубины залегания (Казаков, 1978, рис. 4-11; Чижевский и др. 2011 рис. 5, 6; Лыганов, 2020, рис. 3, 6).
Bce сохранившиеся погребения Мурзихинского II могильника бронзового века были скорченными. Двенадцать погребенных находились на левом боку, четыре на правом, еще у двух погребенных расположение костяка выявить не удалось. Левобочное положение не совсем характерно для погребального ритуала сусканской и луговской культур. Стандартно правобочное положение (Колев, 2000, с. 246; Лыганов, 2018, с. 128-129). На левом боку расположено большинство погре- 
бений могильника Такталачук (Казаков, 1978, рис. 3). При этом преимущественное расположение на левом боку характерно и для ряда хорошо исследованных андроновских и постандроновских могильников Зауралья (Урефты I, Алексеевский, Лисаковский II-VII могильники и др.) (Кривцова-Гракова, 1947, с. 65; Стефанов, Корочкова, 2006, с. 70; Усманова, 2013, табл. 4а). Положение на левом боку, но с ориентировкой в северном секторе характерно для срубной культуры Среднего Поволжья (Семенова, 2000, с. 162; Лыганов, 2019, табл. 1). Семь погребений Мурзихинского II могильника ориентированы головой на юговосток, четыре на восток, три на северо-восток по одному на юг, север, северо-запад. Ориентировка в восточном секторе преимущественно на юго-восток и восток характерна для могильников луговской и сусканской культур и также черкаскульской, культуры юга лесной зоны и лесостепного Зауралья (Колев, 2000, с. 246; Обыденнов, Шорин, 2005, с. 62).

Подкурганные сооружения и следы ритуальных действий. Возле погребений и на такой же глубине в межмогильном пространстве Мурзихинского II могильника зафиксированы развалы посуды. Чаще всего такие развалы сосудов связывают с жертвенными комплексами. Все крупные скопления керамики отмечены только возле групп погребений. Рядом с одиночными погребениями выявлены только единичные фрагменты керамики. Исключением может быть развал сосуда из раскопа $X$, который не относится ни к одному погребению, однако, он размещался у южной стенки раскопа и не исключено, что южнее могли располагаться неизученные погребения (рис. 10: 7). Обычай помещать разбитые сосуды в стороне от погребений, но на глубину совершения захоронения зафиксирован в Коминтерновских курганах и Маклашеевских курганах на взвозе (Чижевский и др. 2011; Лыганов, 2017, рис. 3; Лыганов, 2020, рис. 3). Стоит отметить, что в подавляющем большинстве случаев сосуды из жертвенных комплексов значительно крупнее погребальных и у них отсутствует нижняя часть.

Вне погребальных групп и одиночных погребений культовые сооружения, керамика или другие изделия, которые можно было бы отнести ко времени существования луговской культуры, отсутствуют.

Погребения Мурзихинского II могильника размещались поодиночке или небольшими группами. Возможно, над каждым одиночным погребением и группами погребений в древ- ности был насыпан невысокий курган. Группы и одиночные погребения Мурзихинского II могильника вытянуты с небольшими отклонениями по направлению север-юг. Таким же образом располагались курганы в курганных могильниках луговской культуры - Коминтерновских и Маклашеевских курганах на взвозе (Лыганов, 2017, рис. 1; Лыганов, 2020, рис. 2).

3. Погребальный инвентарь.

Керамические изделия на Мурзихинском II могильнике представлены целыми и разрушенными сосудами из погребений и из жертвенных комплексов. Вся керамика находит полные аналогии в древностях луговской и сусканской культур. Это проявляется в «тюльпановидной» форме сосудов с небольшим отгибом венчика, а также в характерном орнаменте, состоящем из одного ряда или рядов горизонтальных линий, выполненных путем протаскивания гребенки, рядов отдельных наклонных линий, зигзага, заштрихованных треугольников вершинами вниз, горизонтального «елочного» орнамента. Эта керамика характерна не только для погребальных, но и для поселенческих памятников: ЗуевоКлючевской, Подгорно-Байларской, Дубовогривской II, Кумысской, Луговской I стоянок, Больше-Отарского (Балымского) I поселения и др. (Калинин, Халиков, 1954, рис. 33; Халиков, 1980, табл. 24; Ашихмина, 2014, рис. 8, 12, 13, 14; Лыганов и др. 2019).

Наибольшую близость по форме и орнаменту на керамике проявляют близко расположенные Коминтерновские курганы, Соколовский IV могильник, Маклашеевские курганы на взвозе (Казаков, 1992; Чижевский и др. 2011; Лыганов, 2017; Лыганов, 2020). Близость данных некрополей, помимо всего прочего, заключается и в присутствии некоторых признаков поздняковских орнаментальных традиций на луговской по облику керамике. На Мурзихинском II могильнике они отмечены на сосудах из погребений 222 и 224, на которых имеются ряды неровных подтреугольных вдавлений (рис. 11: 3, 5). Из хаотичных рядов овальных и каплевидных небольших вдавлений состоит и орнамент сосуда из жертвенного комплекса группы погребений раскопа I, 1995 г. Подобная орнаментация присутствует на ряде погребальных и поселенческих памятников поздняковской культуры (Ставицкий, 2008, рис. 256-258 и др; Азаров, 2013, рис. 7). В тоже время такие неровные подтреугольные вдавления совсем нехарактерны для андроноидных культур Зауралья. 
В подъемном материале на размытой части Мурзихинского II могильника зафиксированы фрагменты от сосудов, имеющих явные аналогии с черкаскульской керамикой (рис. 8: 3-5). Это развал сосуда, украшенный рядами косоугольных заштрихованных треугольников, выполненных мелким гребенчатым штампом, двумя рядами широких каннелюр и овальными вдавлениями выше и ниже каннелюр, а также фрагмент керамики с фрагментом меандра, выполненным гребенчатым штампом. От луговских сосудов, выявленных в погребениях и в жертвенных комплексах, черкаскульская посуда отличается тщательно заглаженной поверхностью и аккуратностью нанесения орнамента, без сбивок и неровностей заполнения орнаментального поля. Небольшой процент зафиксированной черкаскульской и федоровской керамики является характерной чертой как для погребальных, так и для поселенческих памятников луговской и сусканской культур (Колев, 2000, рис. 9, 10; Лыганов и др., 2019, рис. 9, 10; Лыганов, 2020, рис. 4: 2).

В ряде погребений зафиксированы металлические изделия. Это двулезвийный кинжал, бочонковидная бронзовая бусина, нож с отломанным кончиком, бляшка с двумя отверстиями для навешивания, пронизь, нож и проколка. Все металлические изделия выявлены в погребениях без керамики. Это весьма представительный набор металлических изделий для погребальных памятников сусканской и луговской культур.

Двулезвийный кинжал выявлен под левым предплечьем мужского костяка II погребения 85 (рис. 7: 3, 5). Кинжал имеет черешок, округлый в основании и подчетырехугольный в конце. От клинка его отделяет хорошо выраженный упор, имеющий в сечении округлую форму. Клинок имеет выпуклое ребро, ограниченное от краев лезвия неглубоким (1-2 мм) желобками. Кинжал относится к широко распространенному в позднем бронзовом веке в Северной Евразии типу ножей и кинжалов с клинком остролистной формы и с кольцевидным упором на черенке (Подобед и др., 2009; Бочкарев, 2017, 2017, с. 191). Они относятся к типу Н-36 по Е.Н. Черных (Черных, 1976, c. 120-121, табл. XXXVI). По В.С. Бочкареву такие изделия относятся к лобойковско-дербеденевской группе металлических изделий позднего бронзового века (Бочкарев, 2017, с. 171-173). Для Среднего Поволжья и Прикамья можно выделить дербеденевскую подгруппу, которая связана с одноименным очагом металлопроизводства. Есть все основания относить к данному очагу металлические изделия черкаскульской, сусканской и луговской культур (Бочкарев, 2017, с. 173).

Гораздо меньше общего у кинжала из Мурзихинского II могильника с кинжалами сосновомазинского типа. Так, ребра жесткости у сосновомазинских кинжалов, которых насчитывается от одного до трех, располагаются вдоль центральной оси лезвия и никогда не сдвигаются к краям. На мурзихинском кинжале отсутствуют характерные волюты на перекрестии и нет литой рукояти с грибовидным навершием. Однако близкие сосновомазинским кинжалы Правобережья Днепра типа Н-48/50 по Е.Н. Черных имеют схожее устройство насада в виде черешка подчетырехугольной формы и хорошо выраженный круглый в сечении упор (Черных, 1976, с. 123, табл. XXXVII).

Бочонковидная бронзовая литая бусина выявлена в мужском? погребении-кремации 18 (рис. 5: 1, 3). Это редкий тип украшений для Волго-Камья в позднем бронзовом веке. Некоторые аналогии по форме можно проследить в бусинных наборах погребений алакульско-федоровского могильника Урефты I в лесостепном Зауралье (Стефанов, Корочкова, 2006 , с. 86 , рис. 52). Однако зауральские бусы скручены из тонкой пластины, а не отлиты.

Вообще для андроновского мира характерно большое количество разнообразных бронзовых бус, однако литые бусы чаще имеют несколько иные пропорции, чем бусина из Мурзихинского II могильника (Аванесова, 1991, рис. 5: 27; Умеренкова, 2011). Косвенным свидетельством именно андроновского влияния Зауралья может быть состав металла бусины. Это оловянистая бронза. Во всей серии металлических изделий из погребений луговской культуры Мурзихинского могильника высокий процент олова отмечен только в этом экземпляре. Схожие литые бусы выявлены и в погребениях 203-204 Тлийского могильника Закавказья, которые датируются XVI-XIII вв. до н.э. (Техов, 1977, с. 62, рис. 28: 9).

Нож с отломанным кончиком и с согнутыми боковыми краями насада из погребения 144 (рис. 9: 3) находит аналогии среди металлических изделий более позднего времени. Так, наиболее близким ему по морфологии является нож из Гулькинской стоянки (Збруева, 1960, рис 17: 2) Керамический комплекс этой стоянки, как и собранные, на ее территории металлические ножи относятся к атаба- 
евскому (раннему) этапу маклашеевской культуры (Чижевский и др., 2019, рис. 12: 10-11). Схожие ножи со слабовыраженным черешком и согнутыми боковыми краями насада известны и в ряде других памятников третьей фазы позднего бронзового века Северной Евразии (Збруева, 1960, рис. 17: 2, 3; Аванесова, 1991, рис. 22: 39, 24: 15; Ткачев, Ткачев, 2009, рис. 3: 8; Чижевский и др. 2019, рис. 12: 10).

Бронзовые бляхи с двумя отверстиями для нашивания, подобные найденным в погребении 144 (рис. 9: 4), характерны для андроновских древностей, маклашеевской культуры и др. (Умеренкова, 2011, с. 18; Халиков, 1980, табл. 54). Раннее появление таких изделий в Волго-Камье следует связать все-таки с воздействием традиций андроновской культуры.

Пронизки, скрученные в трубочку из тонкой металлической пластины, подобные находке из погребения 144 (рис. 9: 2), и четы- рехгранная проколка из погребения 85 (рис. 7: 7) Мурзихинского II могильника, имеют широкие хронологические рамки бытования в различных культурах позднего бронзового века Северной Евразии.

Нож из погребения 155 по своим параметрам тоже тяготеет к ножам атабаевского времени (Чижевский и др., 2019, рис. 12). Это нож с покатыми плечиками, плоским черенком без выраженного упора и широким клинком, его наибольшее расширение приходится на участок, прилегающий к плечикам. Его находка в погребении луговской культуры свидетельствует о том, что ножи такого типа появляются уже в середине II тыс. до н.э., но широкое распространение получают уже в более позднее время.

У пяти изделий методом количественного спектрального анализа был определен состав металла (табл. 2). Он характерен в целом для луговских памятников. Примечательно

Таблица 2. Химический состав металлических вещей из погребений (спектральный анализ)

Table 2. Chemical composition of metal objects from the burials (spectral analysis)

\begin{tabular}{|c|c|c|c|c|c|c|c|c|c|c|c|c|c|c|c|}
\hline предмет & $\mathbf{A g}$ & As & Au & Co & $\mathrm{Cu}$ & $\mathbf{F e}$ & Mn & $\mathbf{N i}$ & $\mathbf{P}$ & $\mathbf{P b}$ & Sn & Sb & $\mathbf{Z n}$ & $\begin{array}{l}\text { груп- } \\
\text { па }\end{array}$ & Сплавы \\
\hline $\begin{array}{l}\text { нож } \\
\text { погр.144 }\end{array}$ & 0,026 & 0,013 & 0,0048 & 0,002 & 99,69 & 0 & 0,0069 & 0,06 & 0,05 & 0,0017 & 0,023 & 0,068 & 0,003 & МП & $\mathrm{Cu}$ \\
\hline $\begin{array}{l}\text { бляха } \\
\text { погр.144 }\end{array}$ & 0,0004 & 0,11 & 0,0003 & 0,17 & 97,85 & 1,37 & 0,004 & 0,19 & 0,097 & 0,019 & 0,011 & 0,1 & 0,008 & BУ & $\begin{array}{l}\mathrm{Cu}(\mathrm{Fe}, \\
\mathrm{As}, \mathrm{Sb})\end{array}$ \\
\hline $\begin{array}{l}\text { пронизь } \\
\text { погр.144 }\end{array}$ & 0,038 & 0,018 & 0,0026 & 0,06 & 98,22 & 1,25 & 0,0073 & 0,079 & 0,05 & 0,0011 & 0,011 & 0,0021 & 0,006 & МП & $\mathrm{Cu}(\mathrm{Fe})$ \\
\hline $\begin{array}{l}\text { бусина } \\
\text { погр.18 } \\
\end{array}$ & 0,098 & 0,036 & 0,0054 & 0,0002 & 92,74 & 0,045 & 0,007 & 0,005 & 0,065 & 0,37 & 6,33 & 0,21 & 0,0057 & BУ & $\begin{array}{l}\mathrm{Cu}+\mathrm{Sn} \\
(\mathrm{Pb}, \mathrm{Sb}) \\
\end{array}$ \\
\hline $\begin{array}{l}\text { нож } \\
\text { погр.155 }\end{array}$ & 0,039 & 0,042 & 0,013 & 0,014 & 98,52 & 0,73 & 0,027 & 0,19 & 0,31 & 0,005 & 0,022 & 0,043 & 0,005 & МП & $\mathrm{Cu}(\mathrm{Fe})$ \\
\hline
\end{tabular}

Определение процентного соотношения химических элементов произведены Р.Х. Храмченковой.

почти полное отсутствие значимых примесей мышьяка и сурьмы, которые специфичны для культур финала бронзы и раннего железного века Волго-Камья.

Радиоуглеродная датировка была произведена по костям из погребений 98 и 144 (табл. 3). Анализ по костяку из погребения 98 дал небольшой разброс дат. В калиброванном значении эти даты приходятся на 1538-1400 гг. до н.э. Следует обратить внимание на то, что из всех существующих радиоуглеродных дат, обладающих такой точностью диапазона, она является одной из самых поздних для луговской культуры. При всей схожести в погребальном обряде и керамике между Коминтерновскими курганами и Мурзихинским II могильником, даты погребения 1 из Коминтерновского кургана 1 более древние (табл. 3). Можно предположить, что наиболее поздни- ми захоронениями Мурзихинского II могильника являются одиночные погребения. Это подтверждают как болеепоздняя дата ${ }^{14} \mathrm{C}$, полученная для одиночного погребения 98, так и относительно поздние металлические вещи из погребений 144, 155. Одиночное расположение погребений характерно в целом для атабаевского этапа маклашеевской культуры (Чижевский и др., 2019, с. 106-107). Более ранними являются сгруппированные погребения Мурзихинского II могльника, они представлены следующими группами: 1) 11, 13, 15 , 18,20 ; 2) 83-85; 3) 222, 224, 225. Такая группировка погребений имеет аналогии в более ранних некрополях луговской культуры, где подобным образом организовано использование могильного пространства (групповое расположение погребений и жертвенные комплексы между захоронениями). 
Таблица 3. Радиоуглеродные даты сусканской и луговской культур.

Table 3. Radiocarbon dates of the Suskan and Lugovskaya cultures

\begin{tabular}{|l|c|c|c|c|}
\hline Объект & Шифр лаборатории & Материал & Дата (BР) & Калиброванные даты (calBC) \\
\hline Р.Селитьба II, соор.3 & ГИН-9425а & дерево & $3320 \pm 40$ & $1689-1505(95,4 \%)$ \\
\hline Р.Селитьба II, соор.2 & ГИН-9425в & дерево & $3270 \pm 40$ & $1622-1447(95,4 \%)$ \\
\hline Лебяжинка V, погр.10 & ГИН-9425б & кость & $3110 \pm 110$ & $1614-1055(95,4 \%)$ \\
\hline Студенцы, кург.1, погр.2 & Ох-4260 & кость & $3350 \pm 70$ & $1778-1496(89,6 \%)$ \\
\hline Зуево-Ключевское поселение & БашГИ-57 & уголь & $3210 \pm 150$ & $1883-1110(95,4 \%)$ \\
\hline Мурзиха ІІ погр. 98. & ГИН-9430 & кость & $3200 \pm 40$ & $1538-1400(95,4 \%)$ \\
\hline Мурзиха II погр.144. & ГИН-10040 & кость & $3330 \pm 160$ & $2036-1225(95,3 \%)$ \\
\hline $\begin{array}{l}\text { Коминтерновский курган 1, } \\
\text { погр.1. }\end{array}$ & UОС-13393 & уголь, дуб & $3312 \pm 32$ & $1641-1504(92,2 \%)$ \\
\hline $\begin{array}{l}\text { Коминтерновский курган 1, } \\
\text { погр.1. }\end{array}$ & UОС-13394 & уголь, дуб & $3291 \pm 30$ & $1623-1501(95,4 \%)$ \\
\hline
\end{tabular}

Исходя из представленных данных, можно сделать заключение о том, что одиночные погребения Мурзихинского II могильника относятся к позднему этапу луговской культуры XVI-XV вв. до н.э.

Групповые погребения могильника, вероятно, имеют более раннюю дату. При этом, судя по отсутствию на территории некрополя глиняной посуды атабаевского этапа маклашеевской культуры, к XIV в. до н.э. Мурзихинский II могильник луговской культуры прекратил свое существование. В дальнейшем территорию могильника стали использовать для совершения своих погребений носители маклашеевской культуры финала позднего бронзового века.

\section{ЛИТЕРАТУРА}

Аванесова Н.A. Культура пастушеских племен эпохи бронзы азиатской части СССР (по металлическим изделиям). Ташкент: Фан, 1991. 200 с.

Азаров Е.С. Поселение и грунтовый могильник эпохи бронзы Кораблино // КСИА. 2013. Вып. 230. C. $182-195$.

Ашихмина Л.И. Генезис ананьинской культуры в Среднем Прикамье (по материалам керамики и жилищ) / Археология евразийских степей. Вып. 19. Казань: ИА АН РТ, Отечество, 2014. 298 с.

Бадер О.Н., Попова Т.Б. Поздняковская культура // Эпоха бронзы лесной полосы СССР / Археология СССР / Отв. ред. О.Н. Бадер, Д.А. Крайнов, М.Ф. Косарев. М.: Наука, 1987. С. 131-135.

Беговатов Е.А., Марков В.Н. Мурзихинский II могильник // Археологические памятники зоны водохранилищ Волго-Камского каскада / Отв. ред. П.Н. Старостин. Казань: ИЯЛИ, 1992. С. 57-72.

Бочкарев В.С. Этапы развития металлопроизводства эпохи поздней бронзы на юге Восточной Европы // Stratum plus. 2017. №2. С. 159-204.

Збруева A.B. Памятники эпохи поздней бронзы в Приказанском Поволжье и Нижнем Прикамье // МИА. №80 / Труды Куйбышевской археологической экспедиции Т. ІІІ / Отв. ред. А.П. Смирнов. М.: АН CCCP, 1960. C. 10-95.

Казаков Е.П. Погребения эпохи бронзы могильника Такталачук // Древности Икско-Бельского междуречья / Отв. ред. О.Н. Бадер. Казань: КФАН СССР, 1978. С. 67-108.

Казаков Е.П. Соколовские могильники эпохи бронзы и их относительная датировка // Материалы по археологии Южного Урала / Отв. ред. Н.А Мажитов. Уфа: изд-во БГУ, 1992. С. 35-44.

Калинин Н.Ф., Халиков А.Х. Поселения эпохи бронзы в Приказанском Поволжье по раскопкам 1951-1952 гг. // МИА. № 42 / Отв. ред. А.П. Смирнов. М.: АН СССР, 1954. С. 157-246.

Колев Ю.И. Заключительный этап эпохи бронзы в Поволжье // История Самарского Поволжья с древнейших времен до наших дней. Бронзовый век / Гл. ред. П. С. Кабытов. Самара: СНЦ РАН, 2000. C. 242-301.

Кривиова-Гракова О.А. Алексеевское поселение и могильник // Археологический сборник. Труды ГИМ. Вып. XVII. / Отв. ред. Н.Л. Рубинштейн. М.: ГИМ, 1947. С. 56-169.

Лыганов А.В. Коминтерновский курган №1 луговской культуры в Приустьевом Закамье // Поволжская археология. 2017. №3(21). С. 97-116. DOI: 10.24852/pa2017.3.21.97.116 
Лыганов А.В. Андроноидные традиции в культурах позднего бронзового века лесостепного Поволжья // XXI Уральское археологическое совещание, посвященное 85-летию со дня рождения Г.И. Матвеевой и 70-летию со дня рождения И.Б. Васильева. Материалы Всероссийской научной конференции с международным участием. 8-11 октября 2018 г. / Отв. ред. А.А. Выборнов. Самара: Изд-во СГСПУ, ООО «Порто-Принт», 2018. С. 128-130.

Лыганов А.B. Северная периферия срубной культурно-исторической общности (по материалам памятников Татарстана и Чувашии) // Археологические памятники Оренбуржья. Вып. 14 / Отв. ред. Н.Л. Моргунова. Оренбург: ОГПУ, 2019. С. 103-123.

Лыганов А.В. К вопросу о культурно-хронологической принадлежности двух могильников позднего бронзового века в Волго-Камье (из раскопок А.Х. Халикова) // Поволжская археология. 2020. №3(33). C. 144-158. DOI: $10.24852 / \mathrm{pa} 2020.3 .33 .144 .158$

Лыганов А.В., Морозов В.В., Азаров Е.С. Луговские I и II стоянки и проблема соотношения черкаскульской, луговской и межовской культур в Нижнем Прикамье // Археология Евразийских степей. 2019. №2. С. 38-98.

Марков В.Н., Чижевский А.А. Погребения эпохи бронзы Мурзихинского II могильника // Археологические исследования и музейно-краеведческая работа в Волго-Уральском регионе. Древности, издаваемые российским археологическим обществом. Вып. 36. / Под ред. Б.Я.Ставиского и А.А. Бурханова. Москва-Казань: Gumanitarya (Изд-во ТГГИ), 2003. С. 125-133.

Обыденнов М.Ф., Шорин А.Ф. Черкаскульская культура. Учебное пособие. Уфа: Юридический колледж, 2005. $139 \mathrm{c}$.

Подобед В.А., Усачук А.Н., Цимиданов В.В. Ножи эпохи поздней бронзы с кольцевым упором из Центральной Азии и Сибири и их западные аналогии. // Древности Сибири и Центральной Азии. Сборник научных трудов / Ред. В.И. Соёнова. Горно-Алтайск: ГАГУ, 2009. № 1-2 (13-14). С. 3-16.

Семенова А.П. Погребальные памятники срубной культуры // История Самарского Поволжья с древнейших времен до наших дней. Бронзовый век / Гл. ред. П. С. Кабытов. Самара: СНЦ РАН, 2000. C. 152-208.

Ставицкий B.В. Глава 6. Бронзовый век / Археология Мордовского края: Каменный век, эпоха бронзы / Ред. В.В. Ставицкий, В.Н. Шитов. Саранск: НИИ гуманитар. наук при Правительстве Республики Мордовия, 2008. С. 134-209.

Стефанов В.И., Корочкова О.Н. Урефты I: зауральский могильник в андроновском контексте. Екатеринбург: Уральский университет, 2006. 160 с.

Техов Б.В. Центральный Кавказ в XVI-X вв. до н. э. М.: Наука, 1977. 239 с.

Ткачев А.А., Ткачев, Ал.Ал. Пахомовский комплекс поселения Оськино Болото // Вестник археологии, антропологии и этнографии. 2009. №11. С. 81-89.

Умеренкова O.B. Украшения эпохи бронзы Западной Сибири (археологический и исторический аспекты). Автореф. Дисс. ... канд. ист. наук. Кемерово, 2011. 21 с.

Памятники Лисаковской округи: археологические сюжеты. Сб. ст. / Отв. ред. Э.Р. Усманова. Караганда - Лисаковск: Tengri Ltd, 2013. 336 с., ил.

Халиков А.Х. Приказанская культура / САИ. Вып. В1-24. М.: Наука, 1980. 129 с.

Черных E.H. Древнейшая металлообработка на юго-западе СССР. М.: Наука, 1976. 301 с.

Чижевский A.А. Проблема перехода культур Нижнего Прикамья от поздней к финальной бронзе // Взаимодействие культур в Среднем Поволжье в древности и средневековье / АЭМК. Вып. 27 / Отв. ред. Т.Б. Никитина, Б.С. Соловьев. Йошкар-Ола, 2004. С. 56-61.

Чижевский А.А. Погребальные памятники населения Волго-Камья в финале бронзового - раннем железном веках (предананьинская и ананьинская культурно-исторические области) / Археология Евразийских степей. Вып. 5. Казань: ИИ АН РТ, 2008. 172 с.

Чижевский А.A. Погребения эпохи энеолита Мурзихинского II могильника // Труды II (XVIII) Всероссийского археологического съезда в Суздале. Т. I / Отв. ред. А.П. Деревянко, Н.А. Макаров. М.: ИА РАН, 2008. С. 367-370.

Чижевский А.А., Шипилов А.В. Ранние энеолитические могильники Усть-Камья // ХХІ Уральское археологическое совещание, посвященное 85 -летию со дня рождения Г.И. Матвеевой и 70 -летию со дня рождения И.Б. Васильева. Материалы Всероссийской научной конференции с международным участием. 8-11 октября 2018 г. / Отв. ред. А.А. Выборнов. Самара: Изд-во СГСПУ, ООО «Порто-Принт», 2018. C. $80-84$.

Чижевский А.А., Губин А.С., Лыганов А.В. Коминтерновский курган № 2 // Урало-Поволжье в древности и средневековье. Материалы международной научной конференции V Халиковские чтения / 
Археология Евразийских степей. Вып. 11 / Отв. ред. Ф.Ш. Хузин. Казань: Институт истории АН РТ, 2011. C. 261-271.

Чижевский А.А., Лыганов А.В., Кузьминых С.В. Ранний (атабаевский) этап маклашеевской культуры // Археология Евразийских степей. 2019. № 2. С. 99-123.

\section{Информация об авторах:}

Лыганов Антон Васильевич, кандидат исторических наук, старший научный сотрудник, Институт археологии им. А.Х. Халикова АН РТ (г. Казань, Россия); liganov.anton@yandex.ru

Чижевский Андрей Алексеевич, кандидат исторических наук, старший научный сотрудник, Казанский (Приволжский) федеральный университет; старший научный сотрудник, Институт археологии им. А.Х. Халикова АН РТ (г. Казань, Россия); chijevski@mail.ru.

\section{REFERENCES}

Avanesova, N. A. 1991. Kul'tura pastusheskikh plemen epokhi bronzy aziatskoy chasti SSSR (po metallicheskim izdeliyam) (Culture of the Shepherd Tribes of the Bronze Age in the Asian Part of the USSR (Based on Metal Articles)). Tashkent: "FAN" Publ. (in Russian).

Azarov, E. S. 2013. In Kratkie soobshcheniia Instituta arkheologii (Brief Communications of the Institute of Archaeology) 230. 182-195 (in Russian).

Ashikhmina, L. I. 2014. Genezis anan'inskoi kul'tury v Srednem Prikam'e (po materialam keramiki $i$ zhilishch) (Genesis of the Ananyino Culture in the Middle Kama Area (According to the Ceramics and Dwellings)). Series: Arkheologiia evraziiskikh stepei (Archaeology of the Eurasian Steppes) 19. Kazan: Institute of Archaeology named after A. Kh. Khalikov, Tatarstan Academy of Sciences; "Otechestvo" Publ. (in Russian).

Bader, O. N., Popova, T. B. 1987. In Bader, O. N., Krainov, D. A., Kosarev, M. F. (eds.). Epokha bronzy lesnoi polosy SSSR (The Bronze Age in the Forest Zone of the USSR). Series: Archaeology of the USSR 8. Moscow: "Nauka" Publ., 131-135 (in Russian).

Begovatov, E. A., Markov, V. N. 1992. In Starostin, P. N. (ed.). Arkheologicheskie pamiatniki zony vodokhranilishch Volgo-Kamskogo kaskada (Archaeological Sites in the Area of Water Reservoirs in the VolgaKama Cascade). Kazan: Russian Academy of Sciences, Kazan Scientific Center, G. Ibragimov Language, Literature and History Institute, 57-72 (in Russian).

Bochkarev, V. S. 2017. In Stratum plus. Archaeology and Cultural Anthropology (2), 159-204 (in Russian).

Zbrueva, A. V. 1960. In Smirnov, A. P. (ed.). Materialy i issledovaniia po arkheologii SSSR (Materials and Research in the USSR Archaeology) 80. Moscow: Academy of Sciences of the USSR, 10-95 (in Russian).

Kazakov, E. P. 1978. In Bader, O. N. (ed.). Drevnosti Iksko-Bel'skogo mezhdurech'ia (Antiquities of the Ik and Belaya Interfluves Area). Kazan: Kazan Branch of the USSR Academy of Sciences, 67-108 (in Russian).

Kazakov, E. P. 1992. In Mazhitov, N. A. (ed.). Materialy po arkheologii Iuzhnogo Urala (Materials of the Archaeology of the Southern Urals). Ufa: Bashkir State University, 35-44 (in Russian).

Kalinin, N. F., Khalikov, A. Kh. 1954. In Smirnov, A. P. (ed.). Materialy $i$ issledovaniia po arkheologii SSSR (Materials and Research in the USSR Archaeology) 42. Moscow: Academy of Sciences of the USSR, 157-246 (in Russian).

Kolev, Yu. I. 2000. In Kabytov, I. S. (ed.-in chief). Istoriia Samarskogo Povolzh 'ia s drevneishikh vremen do nashikh dnei. Bronzovyi vek (History of the Samara Volga Region from the Most Ancient to Modern Times. The Bronze Age). Samara: Russian Academy of Sciences, Samara Scientific Center, 242-301 (in Russian).

Krivtsova-Grakova, O. A. 1947. In Rubinshteyn, N. L. (ed.). Arkheologicheskii sbornik (Archaeological Collection of Papers). Series: Proceedings of the State Historical Museum 96. Moscow: State Historical Museum, 56-169 (in Russian).

Lyganov, A. V. 2017. In Povolzhskaya arkheologiya (Volga River Region Archaeology) 21 (3), 97-116. DOI: 10.24852/pa2017.3.21.97.116 (in Russian).

Lyganov, A. V. 2018. In Vybornov, A. A. (ed.). XXI Ural'skoe arkheologicheskoe soveshchanie (21th Urals Archaeological Congress)). Samara: "Samara State University of Social Sciences and Education", "PortoPrint" Publ., 128-130 (in Russian).

Lyganov, A. V.2019. In Morgunova, N. L.(ed.). Arkheologicheskiepamiatniki Orenburzh 'ia (Archaeological Sites of Orenburg Region) 14. Orenburg: Orenburg State Pedagogical University, 103-123 (in Russian).

Lyganov, A. V. 2020. In Povolzhskaya arkheologiya (Volga River Region Archaeology) 33 (3), 144-158. DOI: $10.24852 / \mathrm{pa} 2020.3 .33 .144 .158$ (in Russian). 
Lyganov, A. V., Morozov, V. V., Azarov, E. S. 2019. In Arkheologiia Evraziiskikh stepei (Archaeology of Eurasian Steppes) 2, 38-98 (in Russian).

Markov, V. N., Chizhevsky, A. A. 2003. In Staviskii, B. Ya, Burkhanov, A. A. (eds.). Arkheologicheskie issledovaniia i muzeino-kraevedcheskaia rabota $v$ Volgo-Ural'skom regione. Drevnosti, izdavaemye rossiiskim arkheologicheskim obshchestvom (Archaeological Sudies, Museum and Local Lore Activities in the Volga-Ural Region. Antiquities Published by the Russian Archaeological Society) 36. Moscow-Kazan: "Gumanitarya" Publ. (Tatar State Institute for Humanities), 125-133 (in Russian).

Obydennov, M. F., Shorin, A. F. 2005. Cherkaskul'skaia kul'tura (Cherkaskul Culture). Ufa: "Yuridicheskii kolledzh" Publ. (in Russian).

Soenov, V. I., Trifanova, S. V., Konstantinov, N. A., Shtanakova, E. A. 2009. In Drevnosti Sibiri i Tsentral'noi Azii (Antiquities of Siberia and Central Asia) 1-2.3-16 (in Russian).

Semenova, A. P. 2000. In Kabytov, I. S. (ed.-in chief). Istoriia Samarskogo Povolzh'ia s drevneishikh vremen do nashikh dnei. Bronzovyi vek (History of the Samara Volga Region from the Most Ancient to Modern Times. The Bronze Age). Samara: Russian Academy of Sciences, Samara Scientific Center, 152-208 (in Russian).

Stavitskii, V. V. 2008. Glava 6. Bronzovyi vek (Chapter 6. Bronze Age) In Stavitskii, V. V., Shitov, V. N. (eds.). Arkheologiia Mordovskogo kraia: Kamennyi vek, epokha bronzy (Archaeology of the Mordva Land: Stone Age and Bronze Period). Saransk: Research Institute of the Humanities by the Government of the Republic of Mordovia, 134-209 (in Russian).

Stefanov, V. I., Korochkova, O. N. 2006. Urefty I: zaural'skii mogil'nik v andronovskom kontekste (Urefty I: Trans-Ural Burial Ground in Andronovo Context). Ekaterinburg: Ural University (in Russian).

Tekhov, B. V. 1977. Tsentral'nyi Kavkaz v XVI-Xvv. do. n.e. (Central Caucasus in the 16th-10th cc. BC.). Moscow: "Nauka" Publ. (in Russian)ю

Tkachev, A. A., Tkachev, Al. Al. 2009. In Vestnik arkheologii, antropologii i etnografii (Bulletin of Archaeology, Anthropology and Ethnography) 11, 81-89 (in Russian).

Umerenkova, O. V. 2011. Ukrasheniia epokhi brozy Zapadnoi Sibiri (arkheologicheskii i istoricheskii aspekty (Adornments of the Bronze Age from Western Siberia (Archaeological and Historical Aspects)). Thesis of Diss. of Candidate of historical sciences. Kemerovo (in Russian).

Usmanova, E. R. (ed.). 2013. Pamiatniki Lisakovskoi okrugi: arkheologicheskie siuzhety (Archaeology of Lisakovskiy Area). Karaganda - Lisakovsk: "Tengri Ltd” Publ. (in Russian).

Khalikov,A.Kh. 1980.Prikazanskaia kul tura(ThePrikazanskaya Culture). Series: SvodArkheologicheskikh Istochnikov (Corpus of Archaeological Sources) 1-24. Moscow: "Nauka” Publ. (in Russian).

Chernykh, E. N. 1976. Drevneishaia metallobrabotka na iugo-zapade SSSR (The Earliest Metalworking in the South-West of the USSR). Moscow: "Nauka" Publ. (in Russian).

Chizhevsky A. A. 2004. In Nikitina, T. B., Solov'ev, B. S. (eds.). Vzaimodeistvie kul'tur v Srednem Povolzh'e $v$ drevnosti $i$ srednevekov'e (Interaction of Cultures in the Middle Volga Region in Antiquity and the Middle Ages). Series: Arkheologiia i etnografiia Mariiskogo kraia (Archaeology and Ethnography of Mari Land) 27. Yoshkar-Ola: Mari Scientific and Research Language, Literature, and History Institute, 50-56 (in Russian).

Chizhevsky, A. A. 2008. Pogrebal'nye pamiatniki naseleniia Volgo-Kam'ia v finale bronzovogo - rannem zheleznom vekakh (predanan'inskaia $i$ anan'inskaia kul'turno-istoricheskie oblasti) Burial sites of the population of Volga-Kama in the Final Bronze - Early Iron Ages (pre-Ananyino and Ananyino cultural and historical areals). Series: Archaeology of Eurasian Steppes, 5. Kazan: "Shkola" Publ. (in Russian).

Chizhevsky, A. A. 2008. In Derevyanko, A. P., Makarov, N. A. (eds.). Trudy II (XVIII) Vserossiiskogo arkheologicheskogo s"ezda v Suzdale 2008 g. (Proceedings of the 2nd (18th) All-Russia Archaeological Congress in Suzdal, 2008) I. Moscow: "Nauka" Publ., 367-371 (in Russian).

Chizhevsky, A. A., Shipilov, A. V. 2018. In Vybornov, A. A. (ed.). XXI Ural'skoe arkheologicheskoe soveshchanie (21th Urals Archaeological Congress)). Samara: "Samara State University of Social Sciences and Education", "Porto-Print" Publ., 80-84 (in Russian).

Chizhevsky, A. A., Gubin, A. S., Lyganov, A. V. 2011. In Khuzin, F. Sh. (ed.). Uralo-Povolzh'e v drevnosti i srednevekov'e. V Khalikovskie chteniia (Ural and Volga Area in Antiquity and Middle Ages: 5th Khalikov Readings). Series: Arkheologiia Evraziiskikh stepei (Archaeology of Eurasian Steppes) 11. Kazan: Institute of History, Tatarstan Academy of Sciences, 224-230 (in Russian).

Chizhevsky, A. A., Lyganov, A. V., Kuz'minykh, S. V. 2019. In Arkheologiia Evraziiskikh stepei (Archaeology of Eurasian Steppes) 2, 99-123 (in Russian). 


\section{About the Authors:}

Lyganov Anton V. Candidate of Historical Sciences. Institute of Archaeology named after A. Kh. Khalikov, Academy of Sciences of the Republic of Tatarstan. Butlerov St., 30, Kazan, 420012, Republic of Tatarstan, Russian Federation; ligaant@rambler.ru

Chizhevsky Andrei A. Candidate of Historical Sciences. Kazan (Volga Region) Federal University. Kremlyovskaya St., 18, Kazan, 420000, the Republic of Tatarstan, Russian Federation; Institute of Archaeology named after A.Kh. Khalikov, Tatarstan Academy of Sciences. Butlerov St., 30, Kazan, 420012, Republic of Tatarstan, Russian Federation; chijevski@mail.ru

Статья поступила в журнал 01.12.2020 г. Статья принята к публикации 01.12.2020 г. Авторы внесли равноценный вклад в работу. 

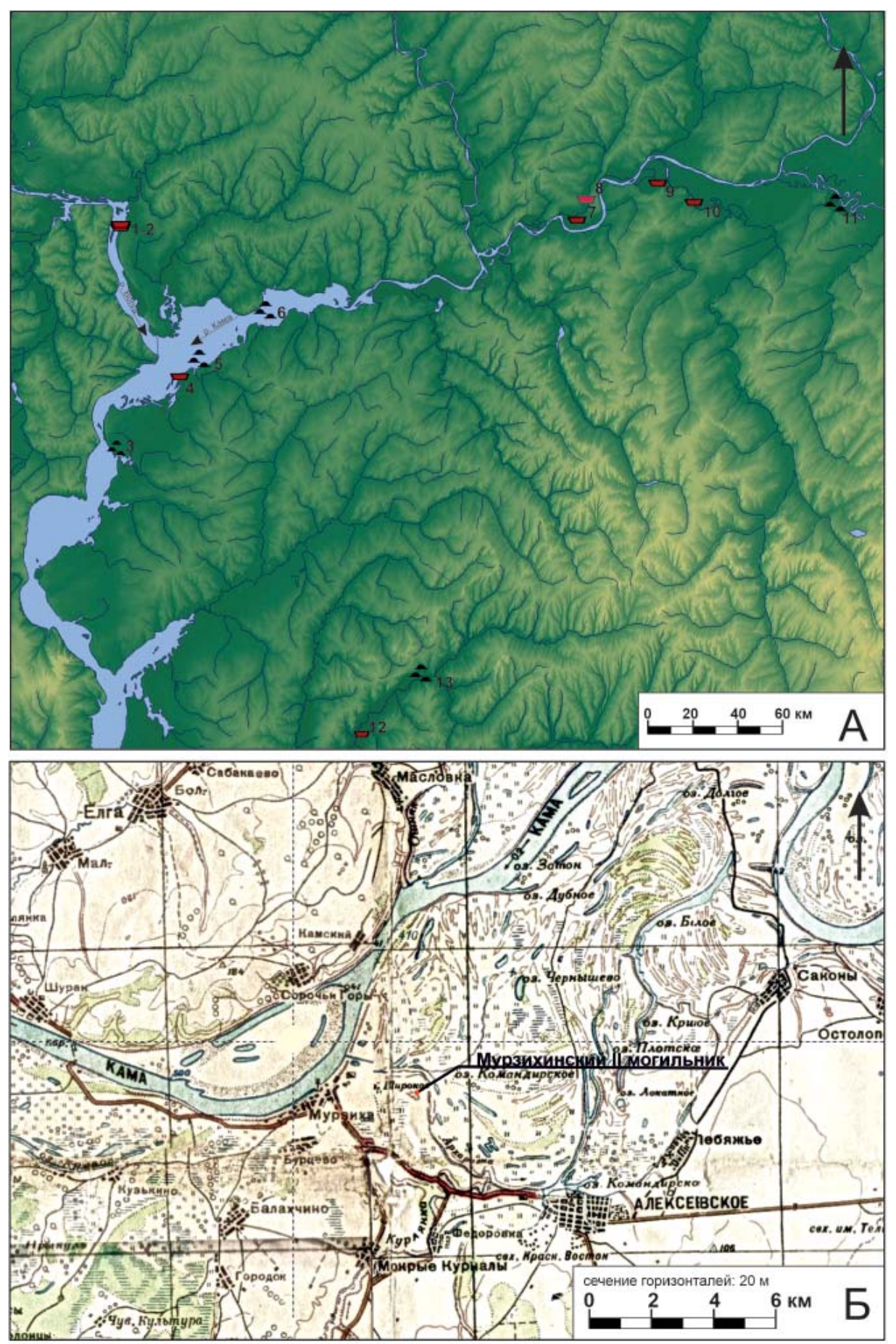

Рис. 1. А. Карта погребальных памятников луговской и сусканской культур: 1 - погребения на Большеотарской (Балымской) стоянке; 2 - Малоотарский могильник; 3 - Маклашеевские курганы на взвозе; 4 - Соколовский IV могильник; 5 - Коминтерновские курганы; 6 - Мурзихинский II могильник; 7 - Коллективное погребениекремация в жилище 1 Луговской І стоянки; 8 - Тихоновский (Пустобаевский) могильник; 9 - Кырнышский II могильник; 10 - Деуковский І могильник; 11 - могильник Такталачук; 12 - погребение на поселении Лебяжинка V; 13 - курган 1 курганного могильника Студенцы. Б. Расположение Мурзихинского II могильника на карте до затопления Куйбышевского водохранилища (топооснова - Карта РККА 1936-1947 гг с масштабом 1:2.5М 1:100К. Источник: http://retromap.ru/).

Fig. 1. A. Map of burial sites of the Lugovskaya and Suskan cultures: 1 - burials at Bolshie Otary (Balym) site;

2 - Malye Otary burial ground; 3 - Maklasheevka uphill barrows; 4 - Sokolovka IV burial ground; 5 - Komintern barrows; 6 - Murzikha II burial ground; 7 - Group burial-cremation in dwelling 1 at Lugovskaya I site; 8 - Tikhonovo

(Pustobaevo) burial ground; 9 - Kyrnysh II burial ground; 10 - Deukovo I burial ground; 11 - Taktalachuk burial ground; 12 - burial in Lebyazhinka V settlement; 13 - barrow 1 of Studentsy burial mound. B. Location of Murzikha II burial ground on the map prior to the flooding of Kuybyshev reservoir (topographic base - Map of the Red Army of 1936-1947 with a scale of 1: 2.5M - 1: 100K. Source: http://retromap.ru/). 

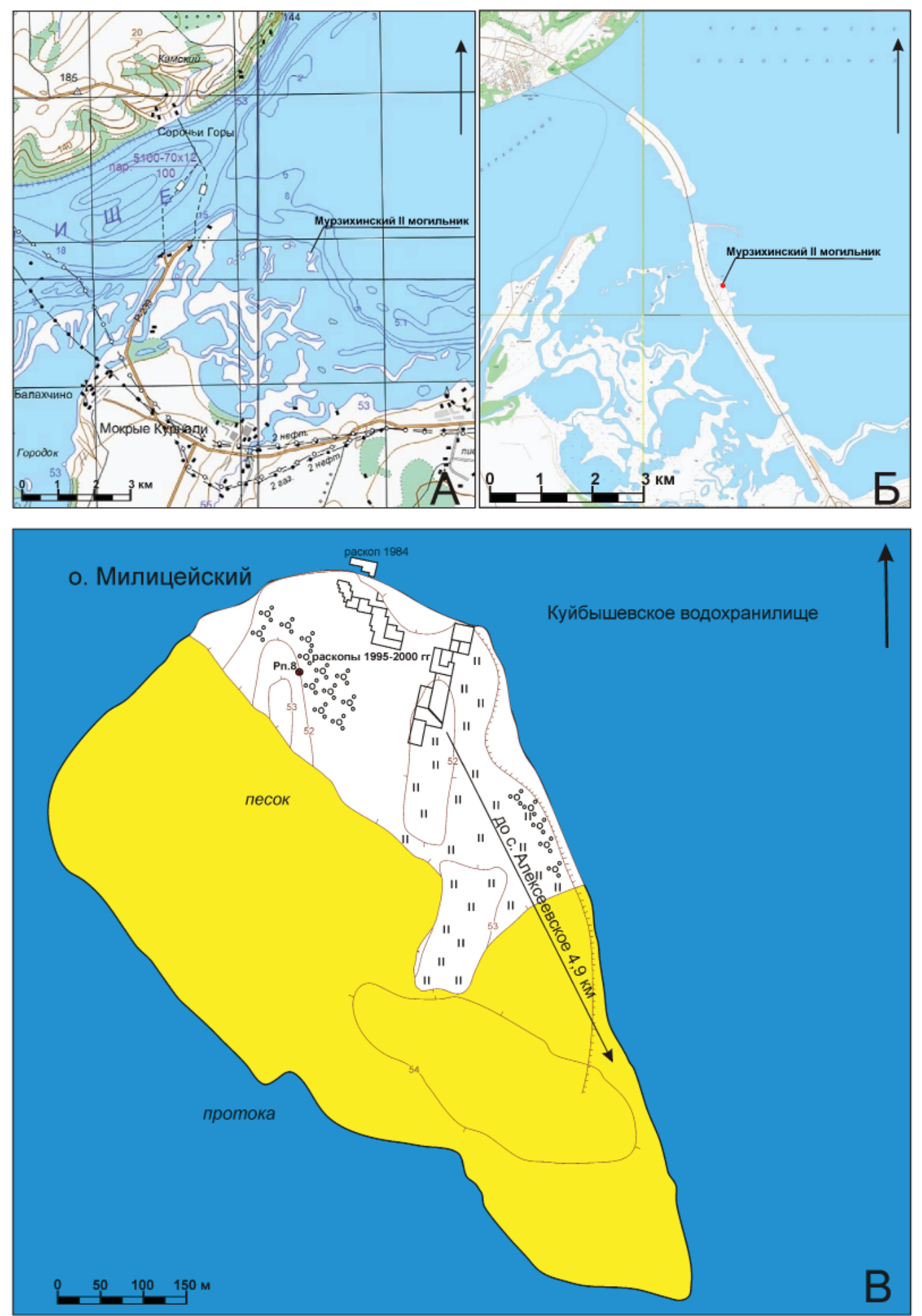

Рис. 2. А. Расположение Мурзихинского II могильника на карте после затопления Куйбышевского водохранилища на о. Милицейский (топооснова - Карта России от ГГЦ 2001 г, масштаб 1:100000. Источник: http://retromap.ru/). Б. Расположение Мурзихинского II могильника после постройки дамбы мостового перехода через р. Кама (топооснова - карта Генерального штаба, М 1:25000, изд. 1999/2010 г., лист N-39). В. План Мурзихинского II могильника на о. Милицейский в 1995-2000 гг. с расположением раскопов

Fig. 2. A. Location of Murzikha II burial ground on the map after the flooding of Kuybyshev reservoir on Militseisky island (topographic base - Map of Russia by GGC of 2001, scale 1: 100000. Source: http://retromap.ru/ ). B. Location of the Murzikha II burial ground after the construction of a bridge dam over the Kama river (topographic base - map of the General Staff, scale 1: 25000, ed. 1999/2010, sheet N-39). C. Layout of Murzikha II burial ground on Militseisky island of 1995-2000 with the location of excavations 


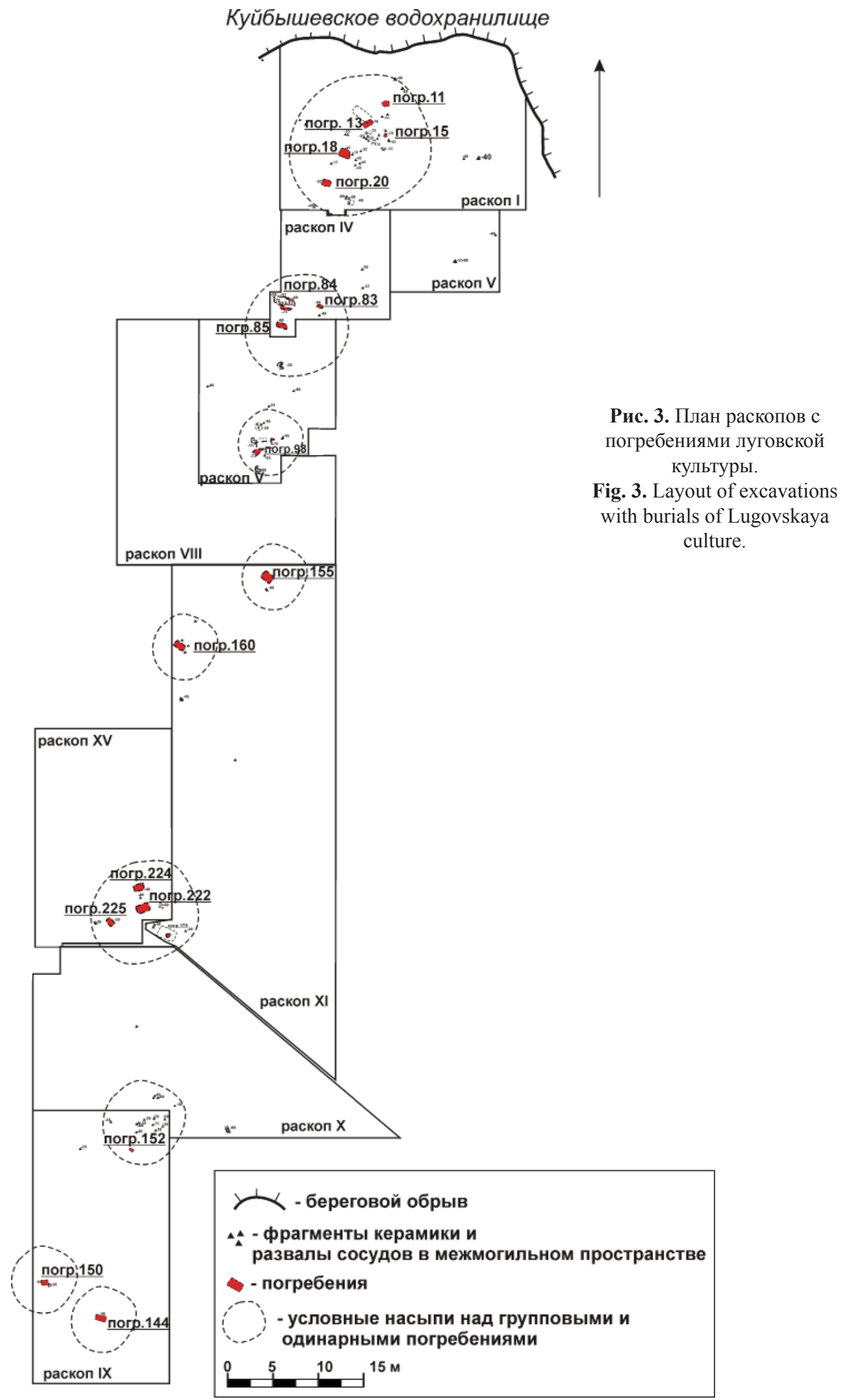



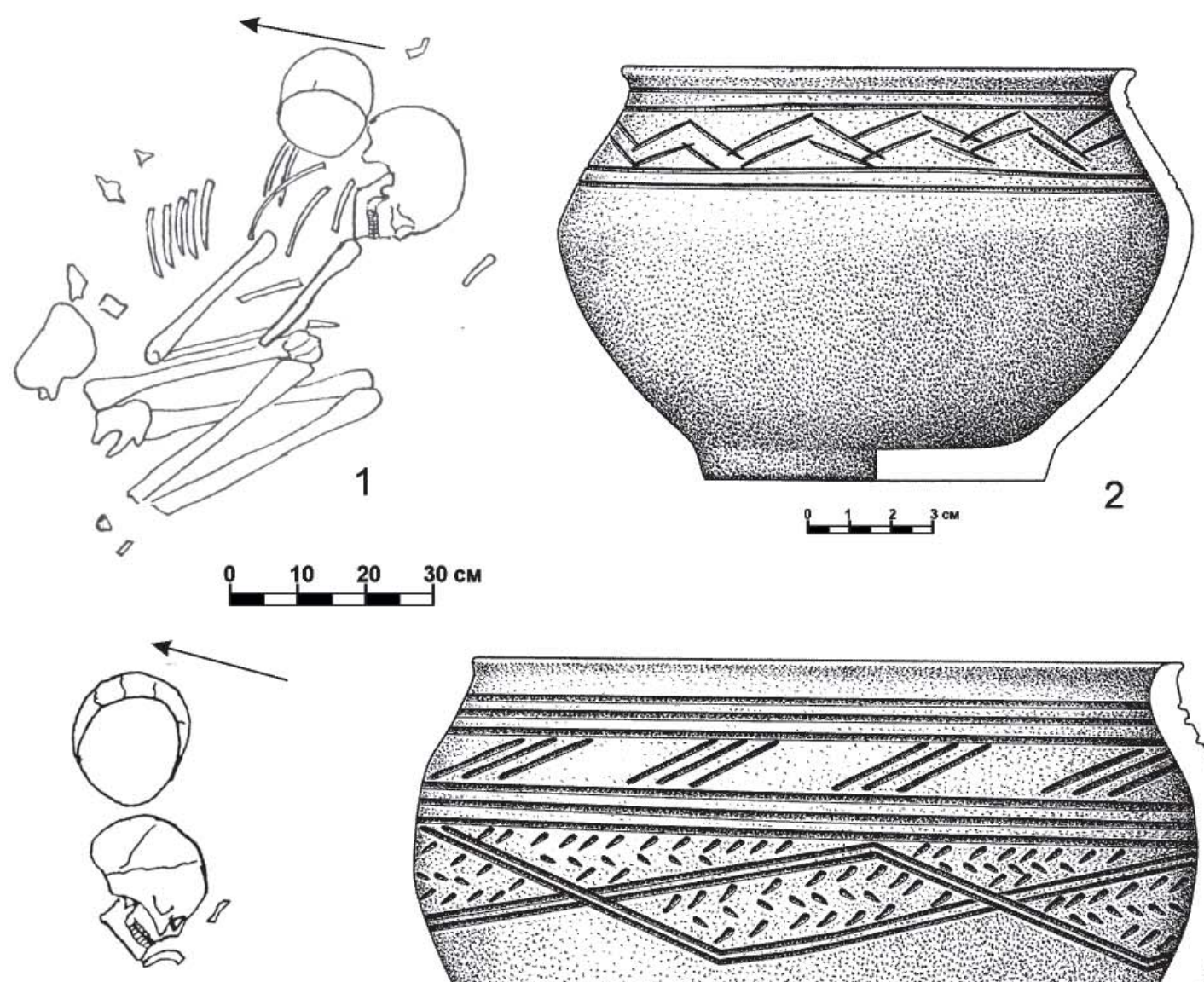

$\checkmark$
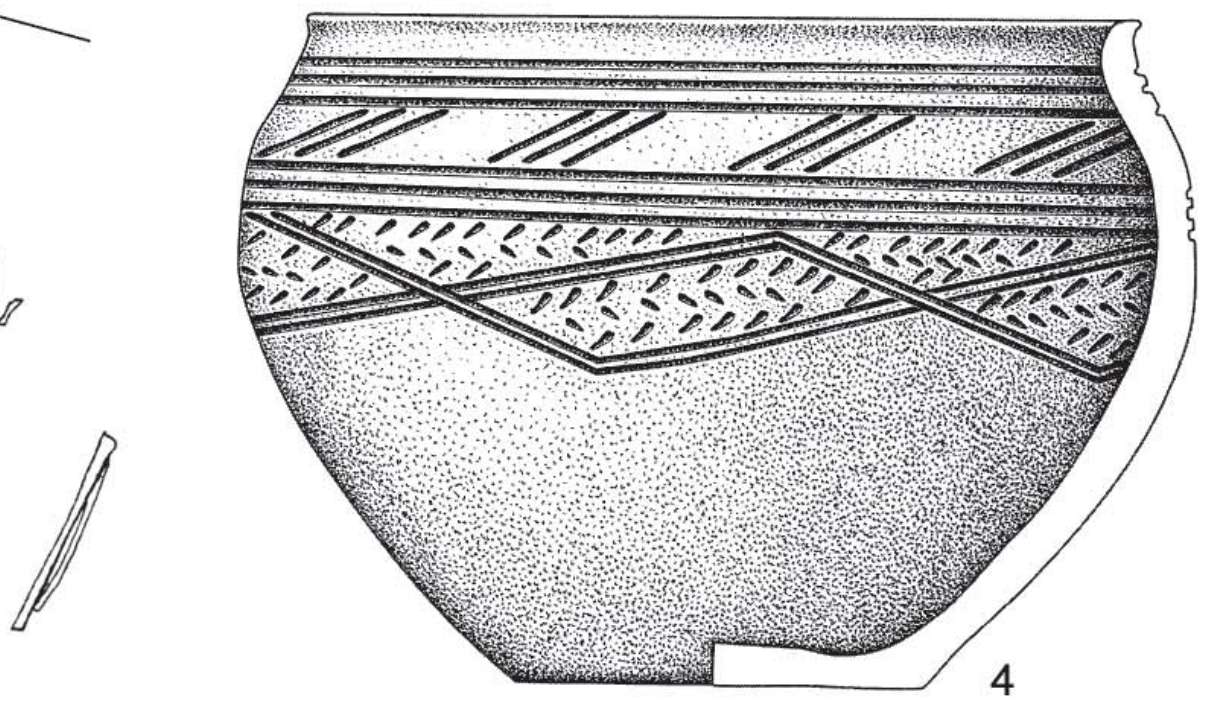

3
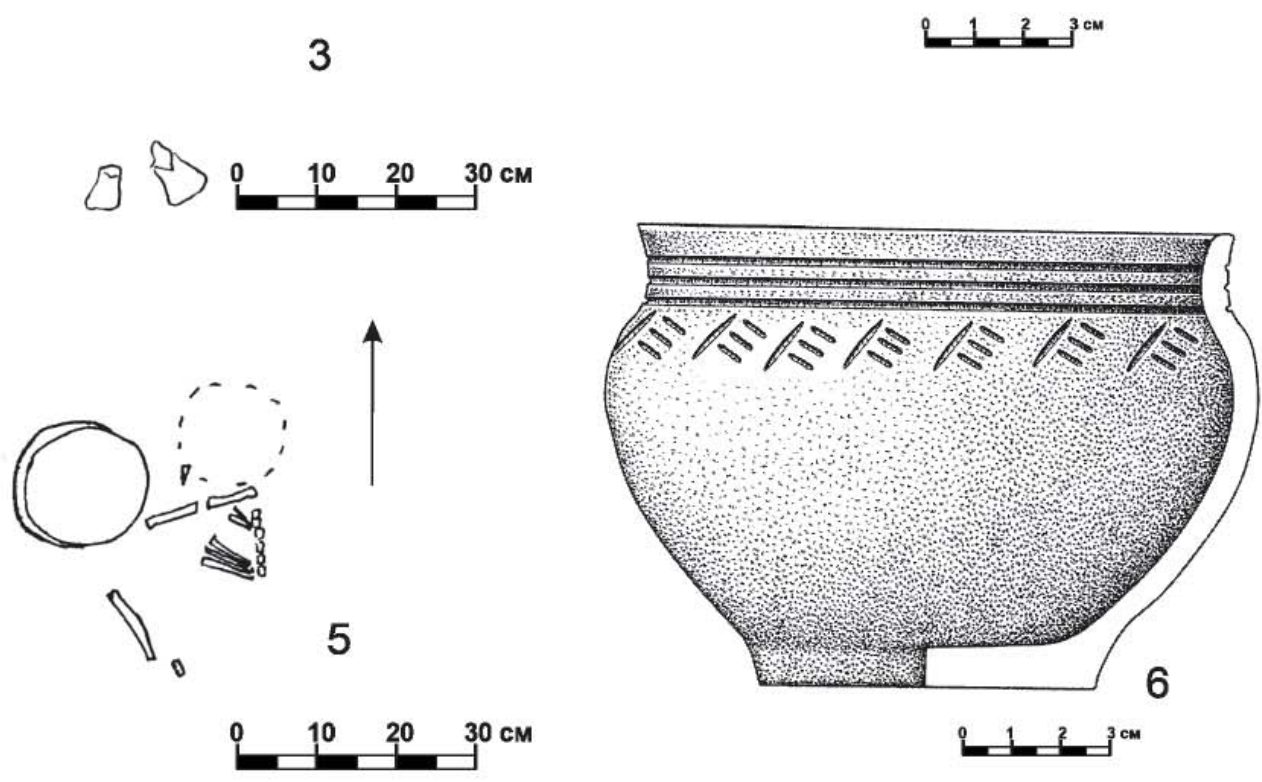

Рис. 4. План погребений и вещевой инвентарь: 1,2 - погр. 11; 3, 4 - погр. 13; 5, 6 - погр. 15. 2, 4, 6 - керамика.

Fig. 4. Layout of burials and inventory: 1,2 - burial 11, 3, 4- burial 13, 5, 6- burial 15. 2, 4, 6 - ceramics. 

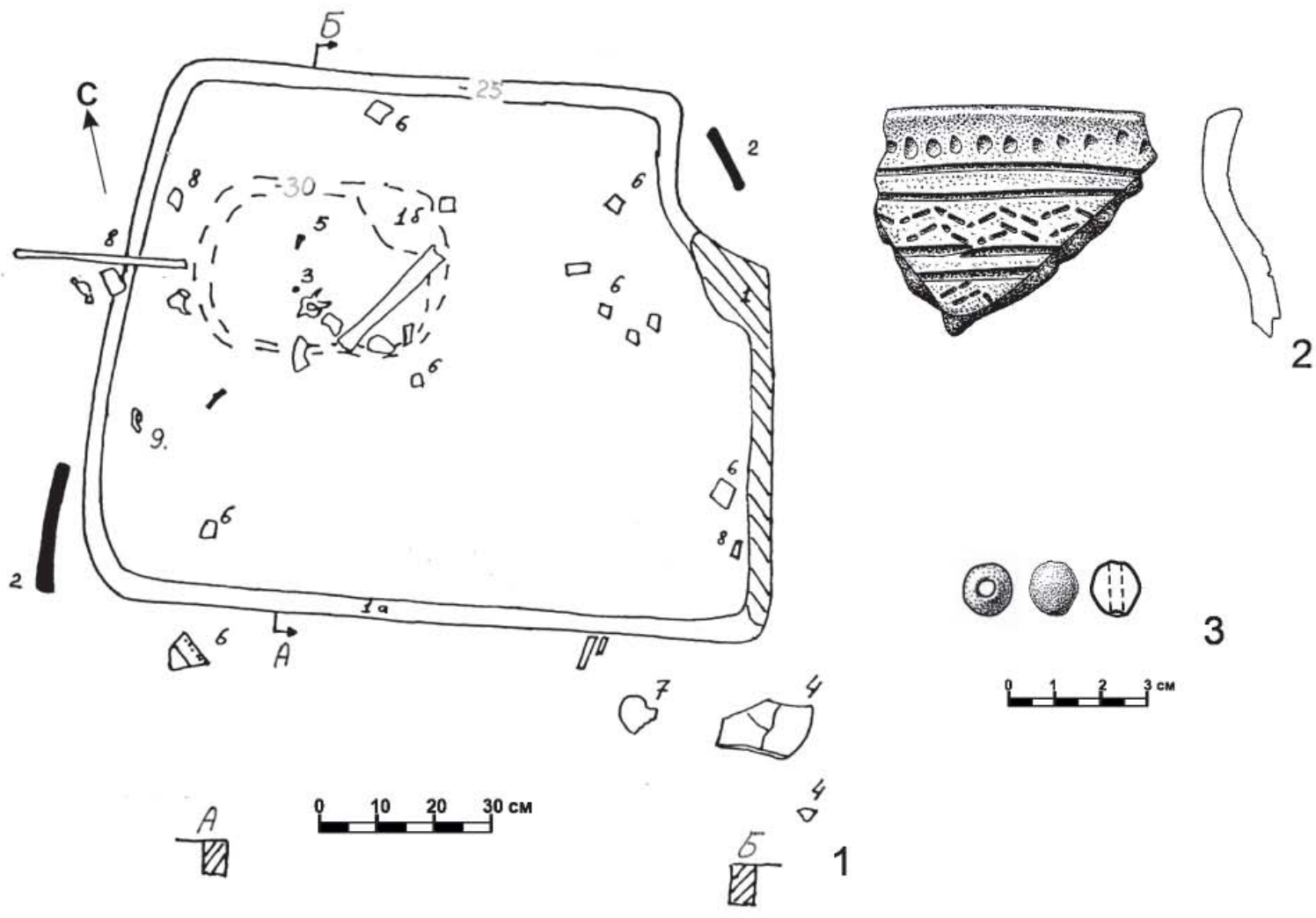

1 - обожженая земля, насыщенная углем: 1а - обожженая земля рыже красного цвета, 16 - обожженая земля тускло красного цвета;

2 - уголь;

3 - бусина бронзовая;

4 - фрагмент таза человека;

5 - зуб пеловека;

6 - фрагмент керамики;

7 - головка бедренной кости;

8 - кости человека;

9 - фрагмент челюсти
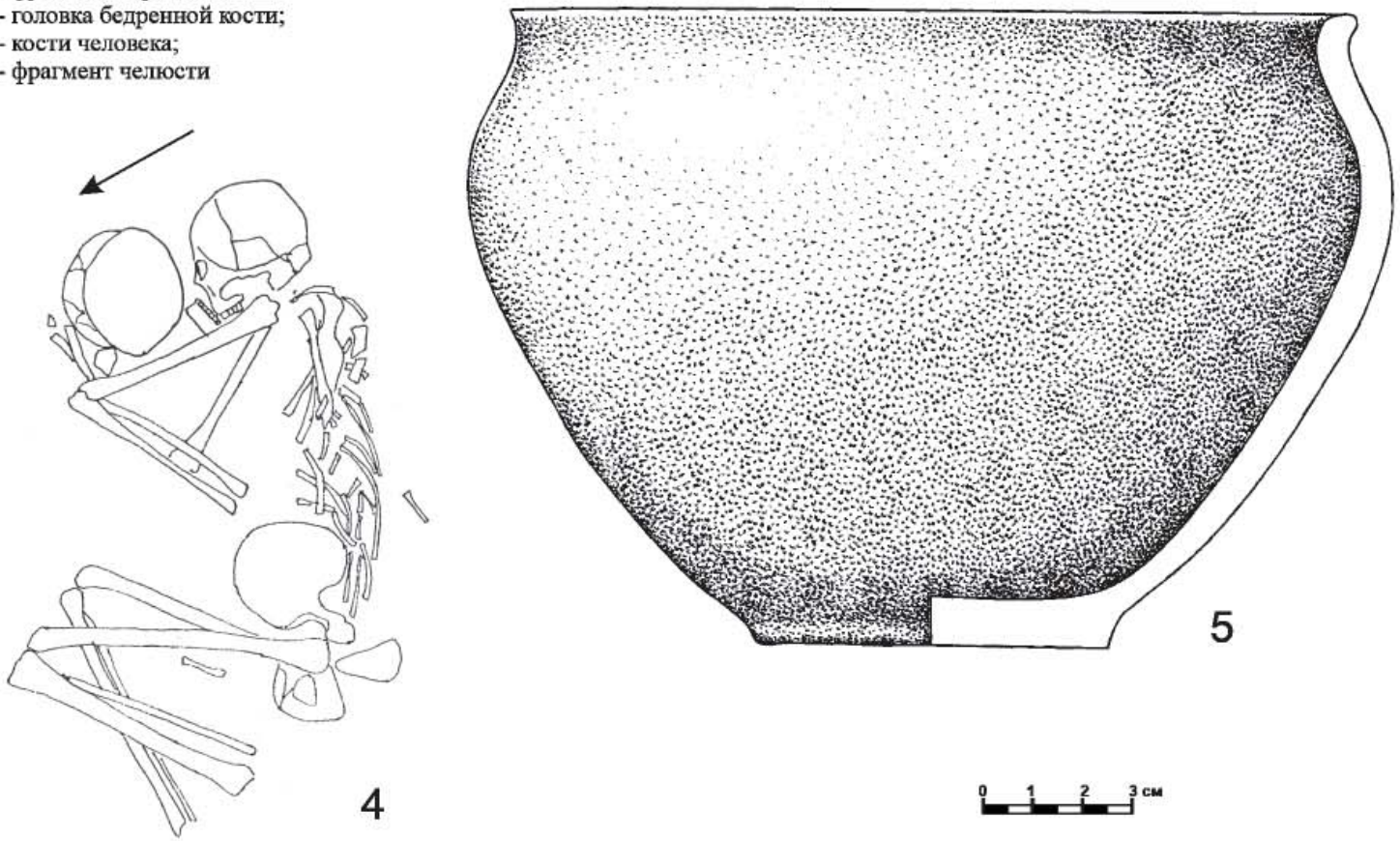

4
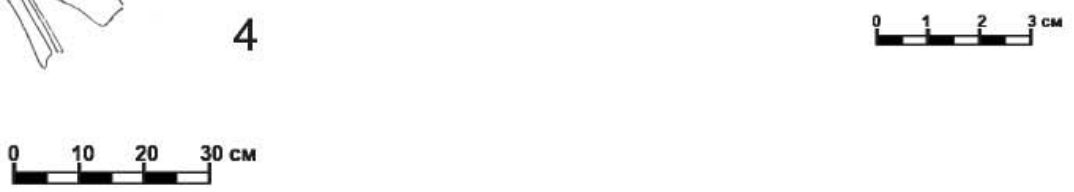

Рис. 5. План погребений и вещевой инвентарь: 1-3 - погр. 18; 4, 5 - погр. 20. 2, 5 - керамика; 3 - бронза Fig. 5. Layout of burials and inventory: $1-3$ - burial 18, 4, 5 - burial 20. 2, 5 - ceramics; 3 - bronze 

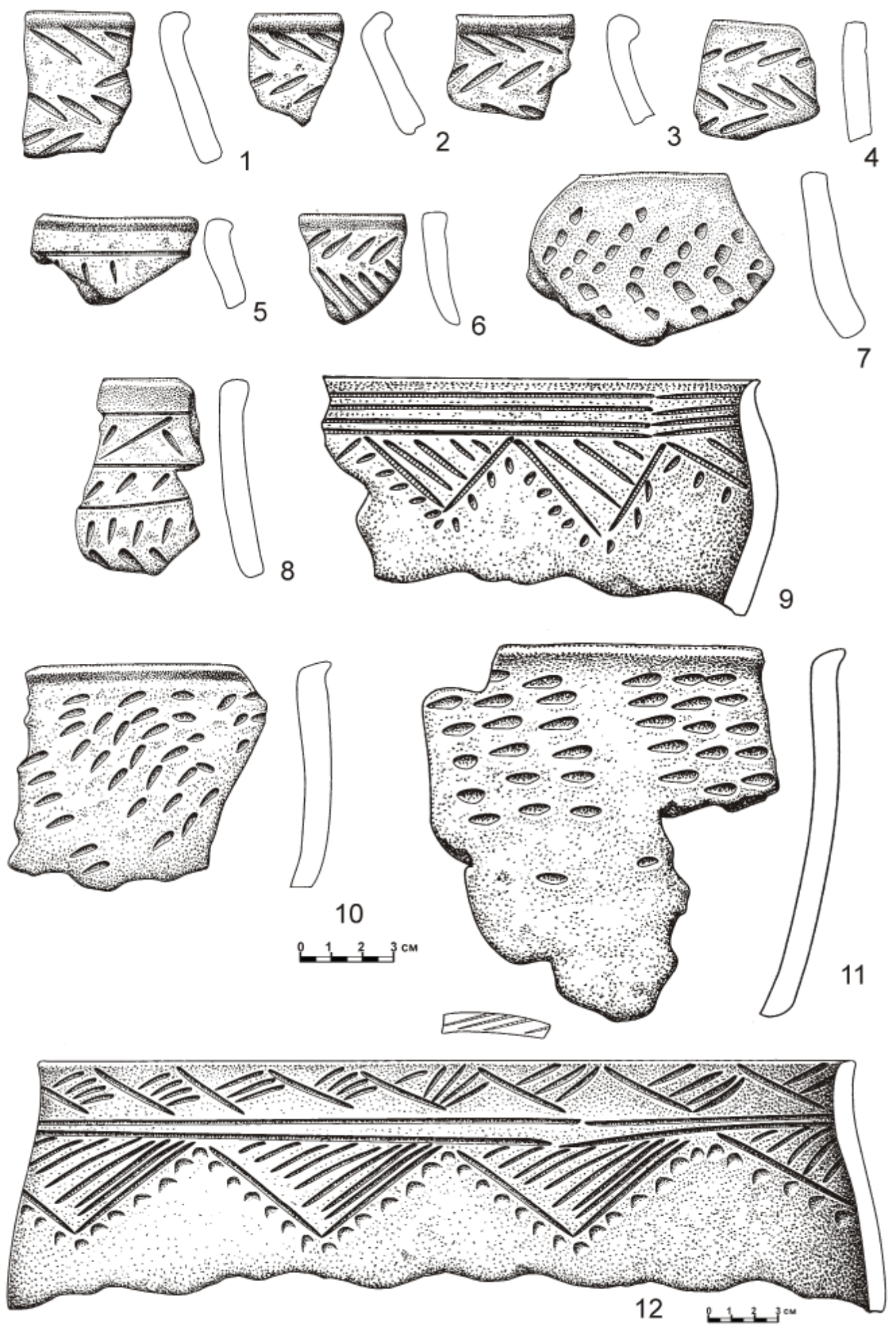

Рис. 6. Керамика и развалы сосудов из жертвенных комплексов группы погребений № 11, 13, 15, 18, 20. Fig. 6. Ceramics and collapsed vessels from the sacrificial complexes of the burial group No. 11, 13, 15, 18, 20. 

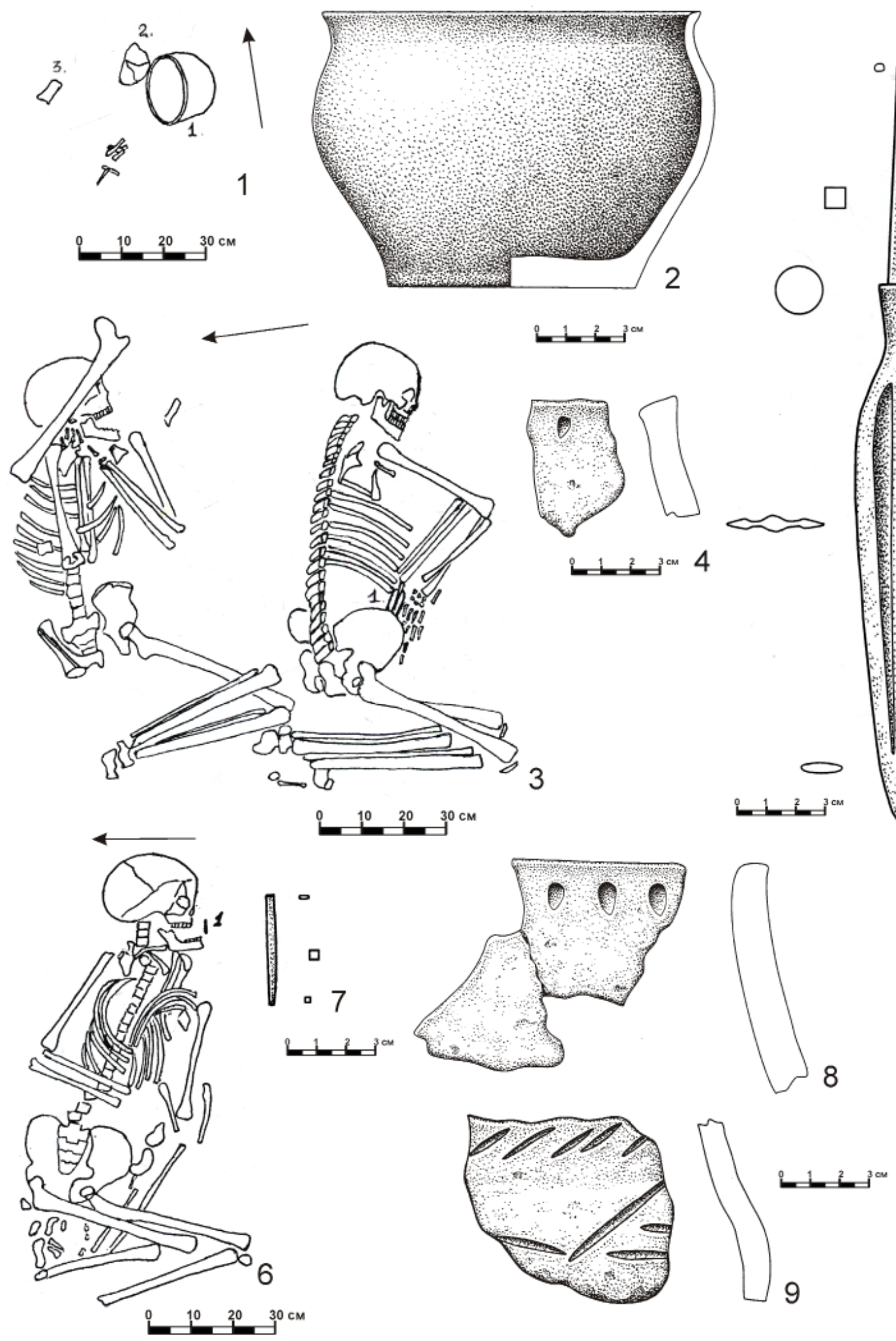

Рис. 7. План погребений и вещевой инвентарь: 1, 2 - погр. 83; 3-5 - погр. 84; 6, 7 - погр. 85. 2, 4 - керамика, 5 - бронза. Фрагменты керамики из межмогильного пространства - 8, 9.

Fig. 7. Layout of burials and inventory: 1, 2 - burial 83, 3-5 - burial 84, 6, 7- burial 85. 2, 4 - ceramics, 5 - bronze. Fragments of ceramics from the space between graves $-8,9$. 

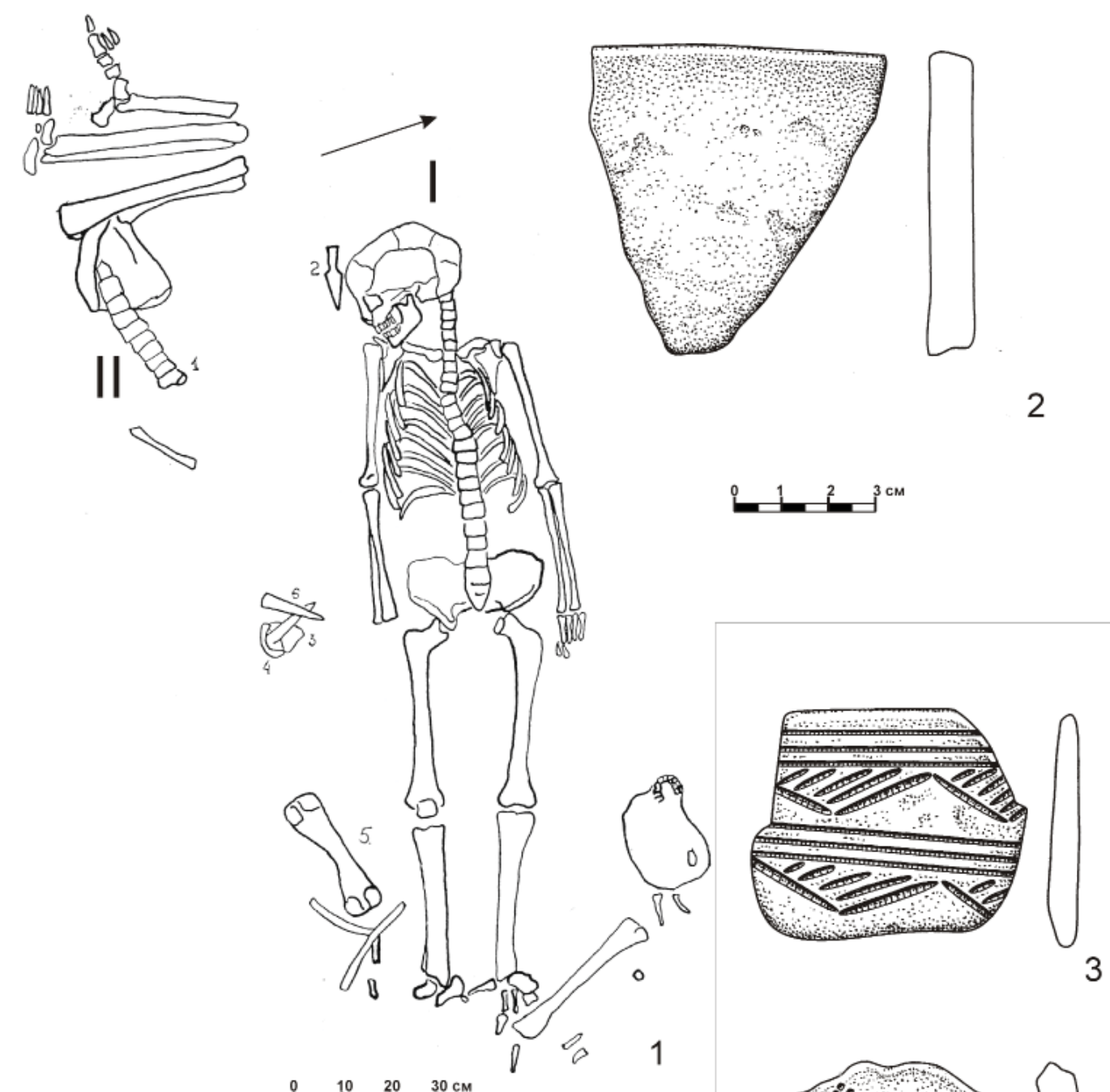

2
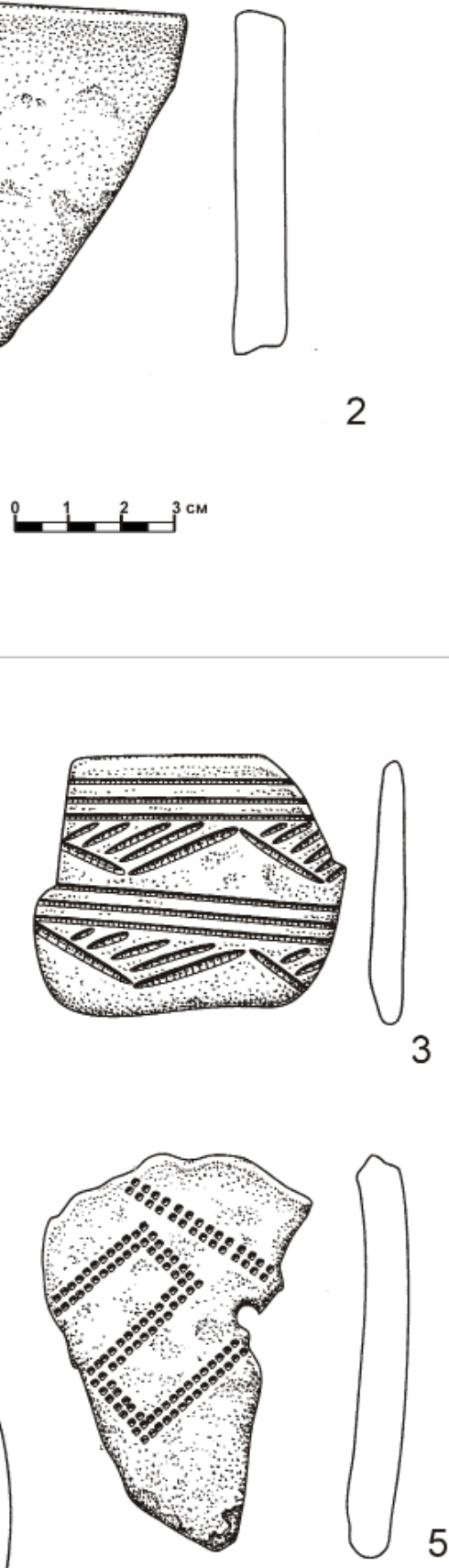

Рис. 8. План разрушенного погребения 98. 1: I - погребение раннего железного века 97, II - разрушенное погребение 98; 2 - керамика из межмогильного пространства; 3-5 - керамика подъемный материал до 1995 г. Fig. 8. Layout of destroyed burial 98. 1: I - burial of the Early Iron Age 97, II - destroyed burial 98; 2 - ceramics from the space between graves; 3-5 - ceramics, material excavated until 1995. 

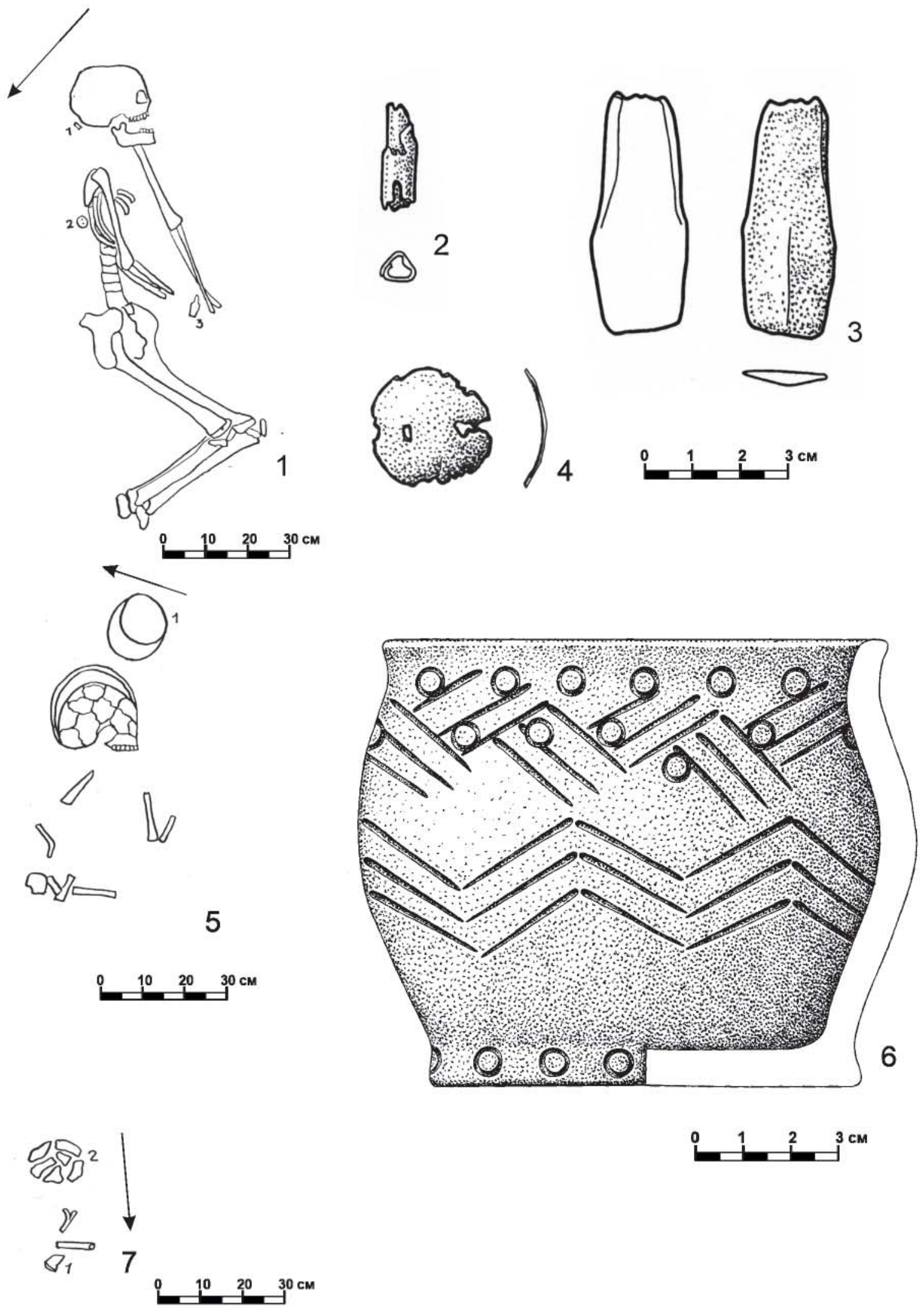

Рис. 9. План погребений и вещевой инвентарь: $1-4$ - погр. 144; 5, 6- погр. 150; 7 - погр. 152. 2-4 - бронза, 6 - керамика.

Fig. 9. Layout of burials and inventory: $1-4$ - burial 144, 5, 6 - burial 150, 7 - burial 152. $2-4$ - bronze, 6 - ceramics. 


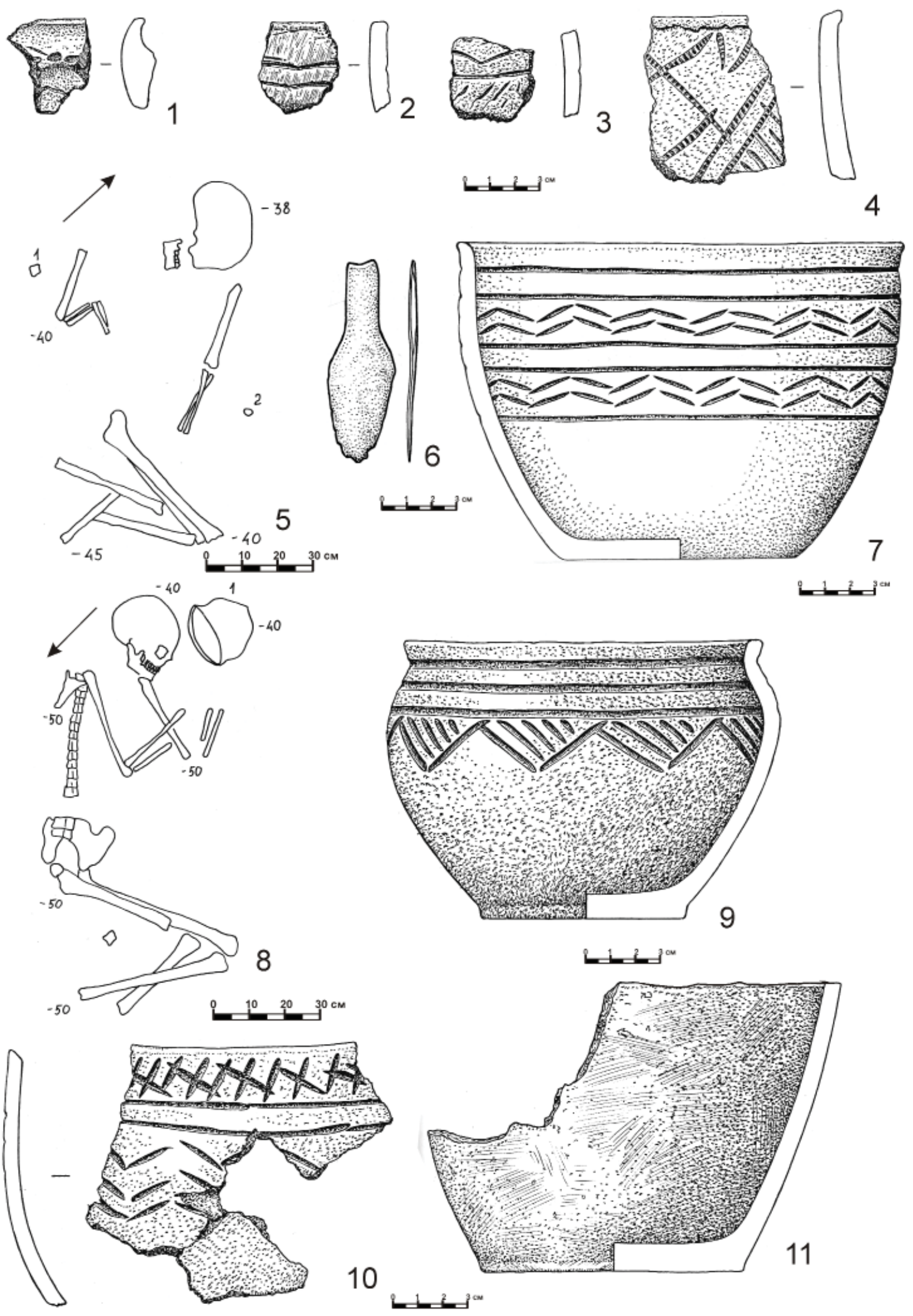

Рис. 10. Фрагменты керамики и развалы сосудов из межмогильного пространства: 1-4, 7, 10, 11. План погребений и вещевой инвентарь: 5, 6 - погр. 155; 8, 9 - погр. 160. 1-4, 7, 9, 11 - керамика, 6 - бронза.

Fig. 10. Fragments of ceramics and collapsed vessels from the space between graves: $1-4,7,10,11$. Layout of burials and inventory: 5, 6 - burial 155, 8, 9 - burial 160. 1-4, 7, 9, 11 - ceramics, 6 - bronze 
$\stackrel{1}{\square}^{-36}$
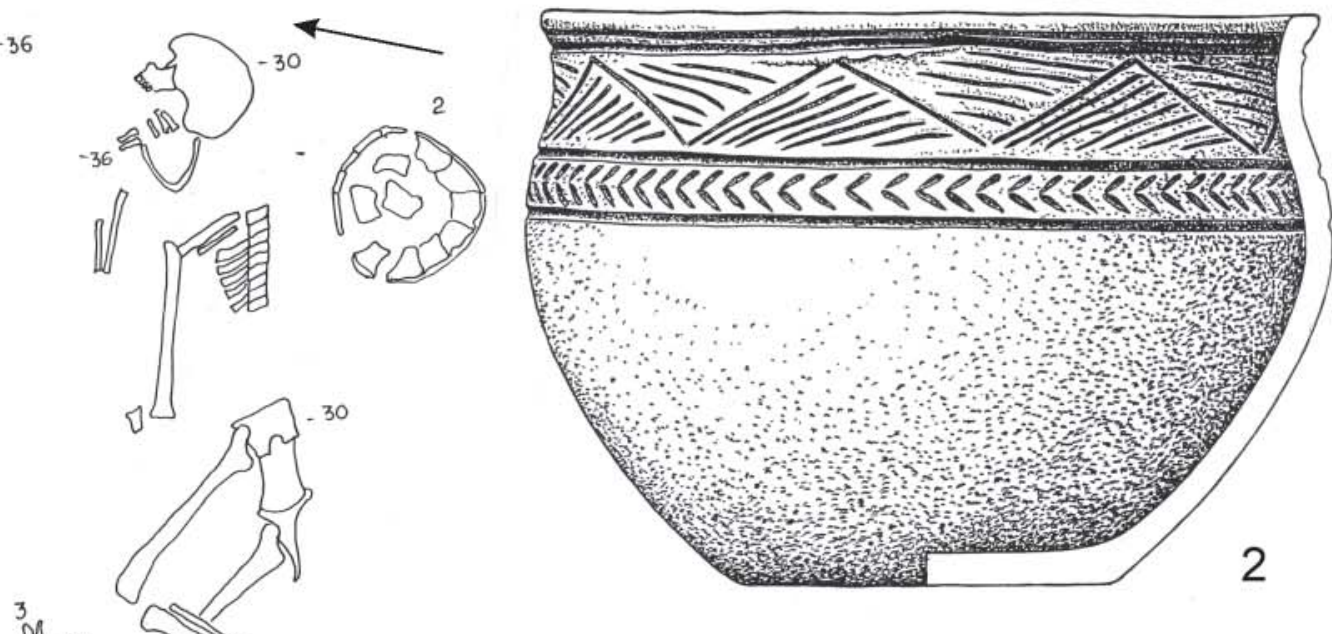

${ }^{3} y-20$
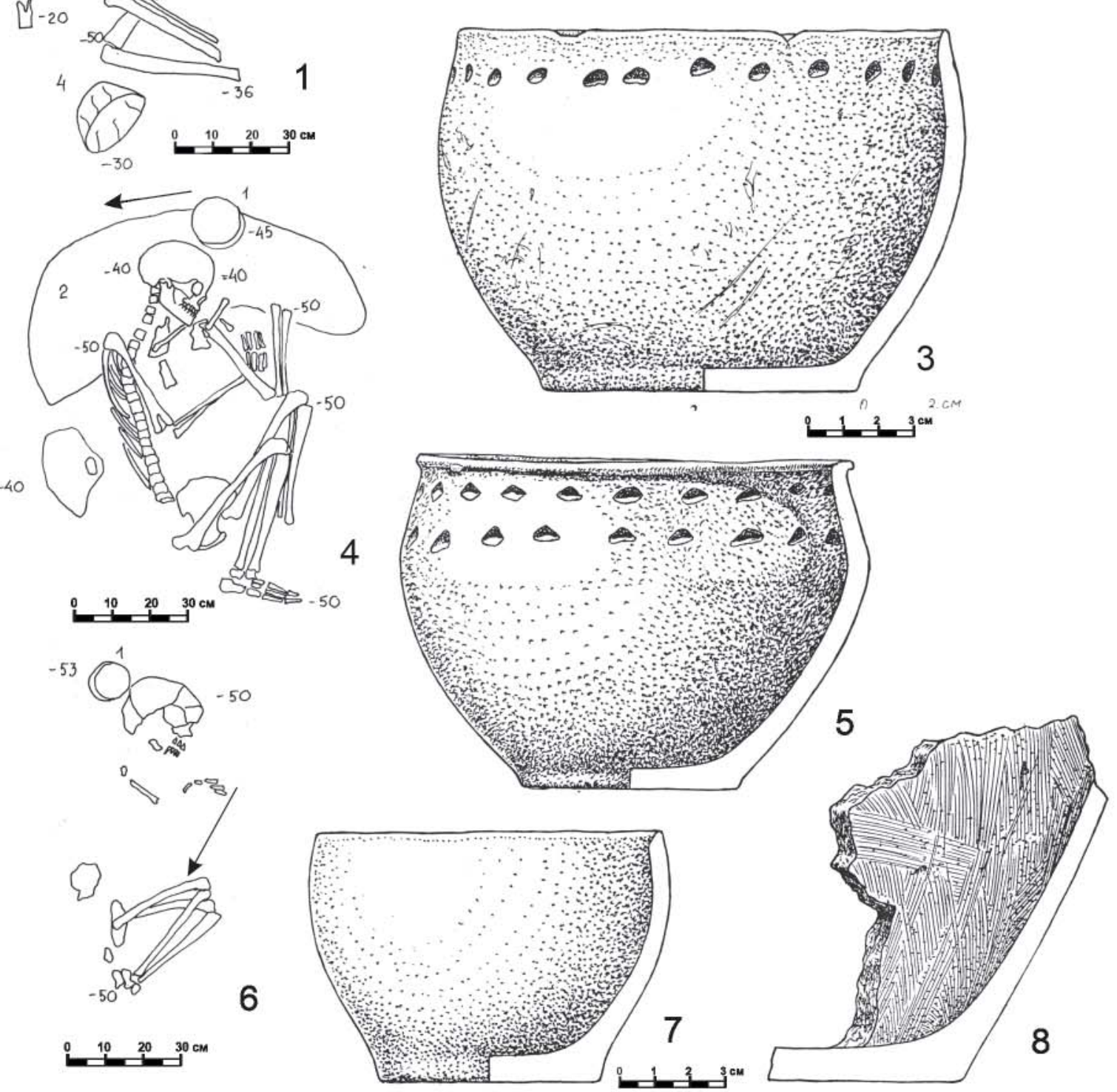

Рис. 11. План погребений и вещевой инвентарь: 1-3 - погр. 222; 4, 5 - погр. 224; 6, 7 - погр. 225. Фрагменты керамики из межмогильного пространства - 8. 2, 3, 5, 7, 8 - керамика.

Fig. 11. Layout of burials and inventory: $1-3$ - burial 222, 4, 5 - burial 224, 6, 7 - burial 225. Fragments of ceramics from the space between graves - 8. 2, 3, 5, 7, 8 - ceramics. 